\title{
A multivariate discrimination scheme of detrital garnet chemistry for use in
}

sedimentary provenance analysis

Raimon Tolosana-Delgado ${ }^{1}$, Hilmar von Eynatten ${ }^{2,}$, Anne Krippner ${ }^{2}$, Guido Meinhold ${ }^{2}$

${ }^{1}$ Helmholtz Zentrum Dresden-Rossendorf, Helmholtz Institute for Resource Technology, Chemnitzer Straße 40, 09599 Freiberg, Germany

${ }^{2}$ University of Goettingen, Geoscience Center Goettingen, Department of Sedimentology and Environmental Geology, Goldschmidtstrasse 3, 37077 Goettingen, Germany

${ }^{*}$ Corresponding author:

Tel.: +495513914958

E-mail address: heynatt@gwdg.de (Hilmar von Eynatten) 


\section{Abstract}

Garnet chemistry provides a well-established tool in the discrimination and interpretation of sediment provenance. Current discrimination approaches, however, (i) suffer from using less variables than available, (ii) subjective determination of discrimination fields with strict boundaries suggesting clear separations where in fact probabilities are converging, and (iii) significant overlap of compositional fields of garnet from different host-rock groups. The new multivariate discrimination scheme is based on a large database, a hierarchical discrimination approach involving three steps, linear discriminant analysis at each step, and the five major host-rock groups to be discriminated: eclogite- $(A)$, amphibolite- $(B)$ and granulite- $(C)$ facies metamorphic rocks as well as ultramafic (D) and igneous rocks (E). The successful application of statistical discrimination approaches requires consideration of the a priori knowledge of the respective geologic setting. This is accounted for by the use of prior probabilities. Three sets of prior probabilities (priors) are introduced and their advantages and disadvantages are discussed. The user is free to choose among these priors, which can be further modified according to the specific geologic problem and the level of a priori knowledge. The discrimination results are provided as integrated probabilities of belonging to the five major host-rock groups. For performing calculations and results a supplementary Excelß spreadsheet is provided.

The discrimination scheme has been tested for a large variety of examples of crystalline rocks covering all of the five major groups and several subgroups from various geologic settings. In most cases, garnets are assigned correctly to the respective group. Exceptions typically reflect the peculiarities of the regional geologic situation. Evaluation of detrital garnets from modern and ancient sedimentary settings of the Western Gneiss Region (Norway), Eastern Alps (Austria) and Albertine Rift (Uganda) demonstrates the power to reflect the respective geologic situations and corroborates previous results. As most garnet is derived from metamorphic rocks and many provenance studies aim at reconstructing the tectonic and geodynamic evolution in the source area, the approach and the examples 
emphasize discrimination of metamorphic facies (i.e., temperature-pressure conditions) rather than protolith composition.

Keywords: garnet; mineral chemistry; linear discriminant analysis; compositional data; prior probabilities; provenance

\section{Introduction}

Sedimentary provenance studies aim at reconstructing source area geology, climate conditions as well as the physical and chemical processes within the drainage system where the material is transported from source to sink (e.g., Johnsson, 1993). Besides bulk sediment composition in terms of framework petrography or whole-rock geochemistry, heavy mineral analysis (e.g., Garzanti and Andò, 2007) and a large variety of single-grain techniques (von Eynatten and Dunkl, 2012) provide prominent tools in sedimentary provenance analysis.

Garnet is among the most frequent heavy minerals in clastic sediment, commonly indicative of the erosion of metamorphic rocks. Garnet further occurs in ultramafic rocks and rarely in igneous rocks. Garnet has a particular wide compositional range as solid solution between the most common endmembers almandine, pyrope, spessartine, grossularite, andradite and uvarovite (Wright, 1938; Grew et al., 2013). Its composition mainly depends on bulk-rock geochemistry, pressure, and temperature and in many cases mirrors metamorphic grade (e.g. Nandi, 1967; Andò et al., 2014). The huge variability in garnet composition and its broad petrogenetic implications has been first used by Andrew Morton in the 1980ies to constrain sediment provenance using chemical analysis of detrital garnet (Morton, 1985). Since then this technique has become widely used in provenance studies (for review see Mange and Morton, 2007). As a note of caution, it must be stated that garnet composition may be affected by diagenetic processes, because Ca-rich garnets are less stable than Capoor garnets and, therefore, detrital garnet populations tend to become less diverse during deep burial (Morton and Hallsworth 2007). 
While first attempts in garnet provenance analysis focused on source discrimination only, later studies attempt to derive petrogenetic interpretations from detrital garnet composition, i.e. the detrital garnets are to be assigned to a specific group of host rocks (e.g., Morton et al., 2004; Mange and Morton, 2007; Win et al., 2007a; Aubrecht et al., 2009). These discrimination schemes are typically based on ternary diagrams using three or four of the major endmembers almandine, pyrope, spessartine and grossularite. Grütter et al. (2004) proposed a mainly binary discrimination scheme for mantle-derived garnet based on $\mathrm{CaO}$ and $\mathrm{Cr}_{2} \mathrm{O}_{3}$ concentrations. Suggate and Hall (2014) proposed a step-wise classification scheme involving more chemical elements and garnet endmembers and using double ternary diagrams. All these discrimination schemes suffer from (i) considering less variables than available for the graphical discriminations, (ii) subjective determination of discrimination fields with strict boundaries (population envelopes or straight lines) in ternary diagrams suggesting clear separation where in fact probabilities are converging and (iii) significant overlap of compositional fields of garnet from different host-rock groups, as convincingly demonstrated by Suggate and Hall (2014) and Krippner et al. (2014).

The drawbacks mentioned before underline the need for an enhanced garnet discrimination scheme, which should build on a comprehensive database and robust multivariate statistics (von Eynatten and Dunkl, 2012; Krippner et al., 2014). In this paper, we present such a discrimination scheme based on (i) a large database covering most of the relevant garnet-bearing rocks, (ii) sensible multivariate statistics considering the compositional nature of garnet geochemical analyses, and (iii) output data in the form of probabilities of belonging to a specific host-rock group instead of strict boundaries. The calculations and results are provided through an Excel ${ }^{\circledR}$ spreadsheet available as Supplementary data (see Appendix A). The scheme has been tested using examples from the literature for both well-defined garnet-bearing crystalline rocks and detrital garnets from sedimentary provenance studies.

\section{Database and structure}


The garnet chemistry database from Krippner et al. $(2014 ; \mathrm{N}=3531)$ is used as a basis for developing a sensible multivariate discrimination scheme. This database covers the common garnet-bearing lithologies and has been compiled from literature data on garnet composition from metamorphic, ultramafic, and igneous rocks from different parts of the world, completed by metamorphic and ultramafic rocks analyzed and reported by Krippner et al. (2014). Garnet chemical composition is defined by concentration of six major element oxides $\left(\mathrm{SiO}_{2}, \mathrm{Al}_{2} \mathrm{O}_{3}\right.$, $\mathrm{MgO}, \mathrm{CaO}, \mathrm{MnO}$, and total iron as $\mathrm{FeO})$ and two trace element oxides $\left(\mathrm{TiO}_{2}, \mathrm{Cr}_{2} \mathrm{O}_{3}\right)$. The database has been filtered for any "non-values" (such as "not analyzed" or "below detection limit") among the major element oxides ( $N=67)$; the treatment of "non-values" among the trace elements, which are much more frequent, is explained further below. The remaining 3464 chemical analyses of single garnet minerals were subdivided into five groups representing the major host-rock groups: eclogite- (A), amphibolite- (B) and granulite- (C) facies metamorphic rocks as well as ultramafic (D) and igneous rocks (E). Moreover, several subgroups have been extracted from the literature information (Table 1).

The eclogite group $(\mathrm{N}=622)$ consists of garnets from mainly metaigneous rocks with some eclogite-facies metasedimentary rocks ( $A 6, N=24)$. Among the former mafic metaigneous eclogites of middle to high metamorphic grade $(A 1, N=283)$ and ultra-highpressure eclogites (A5, $N=290)$ are predominant. The amphibolite group $(N=693)$ consists of garnets from mainly mafic metaigneous amphibolites $(B 1, N=190)$ and amphibolite-facies metasedimentary rocks (B5, N = 446). Garnet from greenschist-facies metasedimentary rocks $(\mathrm{F} 1, \mathrm{~N}=33)$ has been included in the amphibolite group for reasons discussed below. The granulite group ( $\mathrm{N}=452$ ) consists of garnets from roughly equal proportions of mafic metaigneous granulites $(\mathrm{C} 1, \mathrm{~N}=115)$, felsic metaigneous granulites $(\mathrm{C} 2, \mathrm{~N}=166)$ and metasedimentary granulites $(C 5, N=178)$. The ultramafic group $(D, N=958)$ comprises mainly garnet from kimberlites and peridotites (mostly Iherzolithe and harzburgite), and minor pyroxenites. The igneous group consists of 4 subgroups of which only the most common felsic plutonic rocks are included in the discrimination scheme $(E 1, N=463)$. This is because 
garnet from the other three subgroups ( $E 2$, mafic plutonic, $N=75$; $E 3$, felsic volcanic, $N=70$; E4, mafic volcanic, $N=131$ ) have been demonstrated to closely resemble garnet composition from metamorphic lithologies (Krippner et al., 2014). Given the rare occurrence of garnet in rocks of groups E2 to E4 when compared to the bulk mass of garnets as derived from metamorphic and ultramafic rocks, preclusion of garnet from volcanic and gabbroic rocks seems plausible. However, if there is evidence for (i) a significant contribution from volcanic and/or gabbroic source rocks to the sediment in question and (ii) possible occurrence of garnet in these rocks, the discrimination scheme as described here should be used very carefully. Preclusion of these garnets reduces the size of the final data garnet base to $\mathrm{N}=3188$ (Table 1$)$.

\section{Classification strategy}

In order to define an appropriate classification strategy, a series of preliminary descriptive evaluations have been conducted, based on geological considerations and a compositional biplot. A compositional biplot is a graphical representation of a principal component analysis of a compositional data set, previously stripped off all observations with missing values and applied a centered logratio transformation (clr; Aitchison, 1986). It allows a lower dimensional qualitative exploration of a multivariate dataset with respect to the relations among both samples and components. Fig. 1 displays two biplots for the principal components PC1 to PC4, and shows a clear association of $\mathrm{Cr}$-rich and Ti-rich garnets with ultramafic rocks (D), while, for instance, Mn-rich garnets tend to associate with felsic igneous rocks (E). The potential discrimination of garnets from different metamorphic facies is, however, obscured by the fact that the other two groups have a much larger compositional variability, and that $\mathrm{TiO}_{2}$ and $\mathrm{Cr}_{2} \mathrm{O}_{3}$ must be measured on these garnets above the detection limit to appear in the diagrams.

Given the relatively high proportion of missing values for $\mathrm{TiO}_{2}$ (i.e., in many of the literature studies $\mathrm{TiO}_{2}$ content in garnet is not reported) and its redundancy with $\mathrm{Cr}_{2} \mathrm{O}_{3}$, this 
variable was removed from further analysis. The clear association of $\mathrm{Cr}_{2} \mathrm{O}_{3}$-rich garnets with ultramafic rocks has been described by Grütter et al. (2004) and is further explored and illustrated in Figs. 2 and 3. Fig. 2 shows a barplot indicating that from those garnets where $\mathrm{Cr}_{2} \mathrm{O}_{3}$ was measured to be equal or below 200 ppm (i.e., $\leq 0.02$ wt.\%) or not available (i.e., not measured or concentration below the detection limit) about $99 \%$ belong to rock types other than ultramafic. On the contrary, among all garnet with $\mathrm{Cr}_{2} \mathrm{O}_{3}>200$ ppm $\sim 75 \%$ derive from ultramafic rocks. We have chosen a rather low threshold for $\mathrm{Cr}_{2} \mathrm{O}_{3}$, which is only slightly above detection limits with wave-length dispersive electron microprobe techniques, i.e., this information roughly tells if "there is any significant $\mathrm{Cr}$ or not" and allows for very good discrimination of garnet with $\mathrm{Cr}_{2} \mathrm{O}_{3} \leq 200 \mathrm{ppm}$ (Fig. 2). The ratio $\mathrm{MgO} / \mathrm{FeO}$ shows additional high discriminating power for separating ultramafic garnets: roughly speaking garnets with $\mathrm{MgO}>\mathrm{FeO}$ (in wt.\%) can be considered to have an ultramafic origin (Fig. 3A). The combined use of $\mathrm{Cr}_{2} \mathrm{O}_{3}$ and $\mathrm{MgO} / \mathrm{FeO}$ strongly enhances the discriminative power (Fig. 3B).

Once the ultramafic garnets are excluded, the next sensible step is to separate igneous from metamorphic garnets. This is recommended by the biplot that shows a tendency to high MnO-garnets for igneous rocks (Fig. 1, right) and is confirmed by Fig. 4, which shows a comparison of the distribution of the logratios of $\mathrm{MnO}$ to $\mathrm{FeO}$ for garnets from felsic plutonic (E1) vs. metamorphic $(A B C)$ origin. These observations from our database are corroborated by results from Miller and Stoddard (1981) who suggested that manganese enrichment in differentiated peraluminous magmas may be the controlling factor in the paragenesis of most granitoid garnets. The density distribution suggests that garnets having $\mathrm{FeO}<10 \mathrm{MnO}$ (in wt.\%) could be considered of felsic plutonic origin (Fig. 4).

The remaining garnets from metamorphic sources are displayed in the classical garnet ternary diagram with pyrope, grossular, and almandine + spessartine as endmembers and fields of subdivision according to Mange and Morton (2007) (Fig. 5). These fields define a general trend of discrimination which is quite consistent with our large database: while amphibolite-facies garnets are on average lower in grossular ( $\mathrm{Ca}$ ) and pyrope endmembers (Mg) (types Bi and Bii according to Mange and Morton, 2007), eclogite-facies garnets tend to 
be higher in $\mathrm{Ca}$ and $\mathrm{Mg}$ (types $\mathrm{Ci}$ and Cii according to Mange and Morton, 2007) and granulite-facies garnets are at least partly unique through high $\mathrm{Mg}$ and low Ca content (type A according to Mange and Morton, 2007). However, there is strong overlap between groups, mainly in the lower left part (i.e., Fe and/or $\mathrm{Mn}$ rich) of group $\mathrm{Ci}$ where all three facies groups occur in relevant proportions.

From these descriptive evaluations, we extract two partial conclusions. First, it makes more sense to separate garnets in consecutive steps, as suggested by Suggate and Hall (2014), too. In this way, for instance, a maximum use of the partially available $\mathrm{Cr}_{2} \mathrm{O}_{3}$ data can be achieved. As a consequence, we suggest first splitting of garnet from ultramafic rocks from the rest by using the whole composition. Then, without caring about $\mathrm{Cr}_{2} \mathrm{O}_{3}$ anymore, we split magmatic from metamorphic garnets and, finally, metamorphic garnets will be classified according to their respective metamorphic facies (Fig. 6). The second conclusion concerns the final output of such classification tools: most of the classical classification diagrams in petrology or geochemistry show just a set of fields in which the chemistry of a specific mineral or any other kind of chemical or petrological composition is considered to belong to a specific group, without the possibility to consider uncertainty (see above). Given the significant to large overlap of several of these groups, at least in the garnet case, it appears more sensible that the output of such classification effort is the set of probabilities that a given garnet comes from each of the host rock types considered. This will be achieved in the next section with a multivariate statistical approach.

\section{Multivariate statistical discrimination}

\subsection{Method}

The multivariate statistical method used for building each discrimination step is linear discriminant analysis (LDA; Fahrmeir and Hammerle, 1984). This technique is appropriate when the variability of all features used as discriminators is similar between the groups. The set of components $\left[\mathrm{FeO}, \mathrm{MnO}, \mathrm{CaO}, \mathrm{MgO}, \mathrm{Al}_{2} \mathrm{O}_{3}, \mathrm{SiO}_{2}\right]$ were previously transformed with an 
additive logratio transformation (alr) with respect to silica, to account for their compositional nature (Aitchison, 1986; von Eynatten et al., 2003; Tolosana-Delgado, 2012); this is computed as the five logarithms of the ratio of each oxide divided by $\mathrm{SiO}_{2}$. Moreover, given the strong fingerprint of high $\mathrm{Cr}_{2} \mathrm{O}_{3}$ common to most ultramafic rock garnets (Fig. 3), this variable was included in two ways in the discrimination of ultramafic rock garnets from the rest (step 1 in Fig. 6). First, $\mathrm{Cr}_{2} \mathrm{O}_{3}$ was expressed as a threshold variable: if $\mathrm{Cr}_{2} \mathrm{O}_{3}$ is measured $\leq 200$ ppm the respective garnet will be most probably not ultramafic; the exact probabilities will be discussed later in Section 4.3. In case that $\mathrm{Cr}_{2} \mathrm{O}_{3}$ is measured $>200 \mathrm{ppm}$ then the LDA method was used including the five logratios mentioned before as well as the logratio of $\mathrm{Cr}_{2} \mathrm{O}_{3}$ vs. $\mathrm{SiO}_{2}$. For the rest of the discrimination steps, $\mathrm{Cr}_{2} \mathrm{O}_{3}$ was not used in any sense. All calculations were done with the free statistical software R v3.0 ( $R$ core team, 2012); the alr transformation is available in the package "compositions" (alr; van den Boogaart and Tolosana-Delgado, 2013) and the linear discriminant analysis in package "MASS" (Ida; Venables and Ripley, 2002).

Discriminant analysis constructs a discriminant function as a linear combination of the available variables that maximize the differences between groups while minimizing their internal variability. Following the classification strategy developed in the preceding section, we have built three steps of discrimination. The coefficients of the functions obtained in each step can be found in the companion spreadsheet to this article, namely in the respective sheets "pars-LD1", "pars-LD2" and "pars-LD3".

In each of the classification steps, a statistical validation was applied. This consisted in the so-called cross-validation, in which in turn each sample is removed from the dataset and its probability of belonging to each group is predicted by means of a linear discriminant function built without that sample. Finally, the highest probability obtained gives the predicted rock type for each sample. In this way for each sample a true and a predicted rock type are available.

The calculations for discrimination do not consider uncertainty with respect to the measured chemical composition. This appears fully justified because almost all chemical 
data used in this paper (both database and examples) are obtained by wave-length dispersive electron microprobe (EMP) techniques, which are very precise with respect to the elements considered. If the data to be analysed are obtained by other, less precise techniques (for comparison of, e.g., SEM-EDX vs. EMP see for instance Stutenbecker et al., 2017), the uncertainties with the calculated probabilities will be much higher, which is especially relevant if the decision of assigning a garnet to a specific group is somewhat ambiguous.

\subsection{Setting prior probabilities}

Linear discriminant analysis requires the user to set some prior probabilities (priors) that can be interpreted as the subjective likelihood that a given garnet belongs to each group before looking at its chemical classification. These act then as a perturbation with the evidence for each rock type obtained from the garnet composition: when the composition of a garnet strongly suggests a particular rock type, these prior probabilities have no influence at all; on the other hand, when the data do not provide evidence in favour of any origin, one is actually just left with the prior probabilities. Interestingly, these prior probabilities do not change the coefficients of the discriminant functions. This allows for de-coupling the estimation of the discriminant function coefficients from the prior probabilities. The former were estimated from the database as reported in the following sections, while the latter can be approximated with the following considerations.

If all rock types are equally 'fertile' (e.g., Moecher and Samson, 2006) in garnet sediment generation, and ignoring effects of climatic and topographic variability on the differential erosion of rocks (e.g., Riebe et al., 2015), then the prior probabilities could be taken as the proportions of the rocks exposed at the surface in the source area. As default values, results from Dürr et al. (2005) are taken here to represent global Earth values. Regarding the major garnet host-rock groups $A, B, C, D$ and $E$, the following estimates are relevant: mafic to ultramafic plutonic rocks (mostly peridotites and gabbros in ophiolite complexes) represent $0.2 \%$ of the Earth surface, felsic plutonic rocks represent $7.23 \%$, undifferentiated 
metamorphic rocks account for $4.07 \%$ while 'Precambrian basement' (medium- to high-grade metamorphic rocks of predominantly granodioritic to granitic character) represent $11.52 \%$, and a 'complex lithology' category comprising the inner zones of young orogens mainly composed of volcanic and sedimentary rocks but including also some metamorphic and plutonic rocks represents $5.45 \%$. The rest of the surface is covered by volcanic rocks and predominantly sediments, mostly irrelevant for the goals of this contribution.

Based on these estimates we infer (i) to consider the influence of gabbros irrelevant and take $0.2 \%$ as the default frequency of group D, (ii) add $10 \%$ of the 'complex lithology' to felsic plutonics, thus having $7.78 \%$ of $E 1$ and (iii) sum up metamorphic rocks and add another $10 \%$ of the 'complex lithology', thus having a total of metamorphic rocks $A B C$ of $16.68 \%$. To split the metamorphics in the three facies considered, a simple 1 to 25 to 5 ratio is considered for the proportions of eclogite $(A)$ to amphibolite $(B)$ to granulite $(C)$, respectively. These proportions must still be weighted with the typical amounts of garnets in each group. Here we chose a rough estimate of $40 \%$ for eclogite-facies rocks, $5 \%$ for amphibolite-facies rocks, $20 \%$ for granulite-facies rocks, $2 \%$ for ultramafic rocks, and $0.5 \%$ for felsic plutonic rocks. Finally, the two proportions must be multiplied and the result closed to sum to 1 in order to obtain the prior probabilities. All these numbers are listed in the companion spreadsheet under sheet 'priors'.

Note that the numbers provided are rough estimates and intended as a sort of default global values (prior 'global'). This prior should be used if no other evidence is available that places constraints on the specific geologic question or setting to be investigated. Users actually wishing to use the provided classification system can and should adapt these numbers to their geological setting (see discussion in Section 5.2). This can be done either by modifying the rock type proportions and/or the garnet modal proportions, or the blue fields of the final prior probabilities directly (sheet 'prior' in the companion spreadsheet). Note that the prior probability cannot be zero; if a specific group is considered extremely unlikely, you may chose a small value like $0.01,0.001$ or even smaller as prior probability for this group. Two additional priors are introduced later in the text (see Section 5.2). 


\subsection{Discriminating ultramafic garnets ( $D$ vs. all other)}

The first discrimination step is the separation of ultramafic garnets (D) from the garnets from all other sources (A, B, C, E1). This is obtained by using all alr-transformed components, including the alr of $\mathrm{Cr}_{2} \mathrm{O}_{3}$ vs. $\mathrm{SiO}_{2}$ in case that $\mathrm{Cr}_{2} \mathrm{O}_{3}$ is measured and reported to be above $200 \mathrm{ppm}$. If $\mathrm{Cr}_{2} \mathrm{O}_{3}$ is not reported, below detection limit or $\leq 200 \mathrm{ppm}$, then the garnet is given a negligible probability of belonging to D. Using linear discrimination function 1 (LD1), ultramafic garnets are well separated from the rest (Fig. 7). This function, however, only considers garnets with $\mathrm{Cr}_{2} \mathrm{O}_{3}>200$ ppm. As mentioned, for garnets with $\mathrm{Cr}_{2} \mathrm{O}_{3} \leq 200$ ppm this function cannot be used because for many of these numbers are not available (see above) and therefore prior probabilities must be used. The results of the cross-validation, as reported in Table 2 for all garnets independent of $\mathrm{Cr}_{2} \mathrm{O}_{3}$ content, indicate an excellent agreement between true and predicted rock types with a misclassification rate below $3 \%$.

\subsection{Discriminating igneous (E1) from metamorphic $(A B C)$ garnets}

In the second discrimination step, igneous (E1, i.e., felsic plutonic) garnet is separated from garnet derived from metamorphic host rocks. This is obtained by using the alr-transformed components; $\mathrm{Cr}_{2} \mathrm{O}_{3}$ is no longer considered in any way. Fig. 8 displays the probability density estimates and boxplots of the scores of linear discriminant function 2 (LD2) by group, showing very well separation of the felsic plutonic garnets from the metamorphic garnets. The results of the cross-validation indicate again an excellent agreement between true and predicted rock types with an overall misclassification rate of about $6 \%$ (Table 3), i.e., the rate of correct classification is far above $90 \%$.

\subsection{Discriminating garnets of different metamorphic facies $(A B C)$}

The third step according to Fig. 6 is the classification of metamorphic garnets into the three main facies groups: eclogite $(A)$, amphibolite $(B)$ and granulite $(C)$ facies; the amphibolite group includes some metasedimentary greenschist-facies garnets ( $F 1$; see Table 1$)$. As 
expected (see Fig. 5 and previous work by, e.g., Mange and Morton, 2007; Krippner et al., 2014) this step does not deliver such a clear and highly successful discrimination as the two preceding steps. The overall misclassification is about $25 \%$ of all metamorphic samples, and the lowest rate of correct classification is as low as $\sim 50 \%$, obtained for the granulite-facies garnets (C) (Table 4). Note, however, that with sample sizes of $N_{A}=622, N_{B}=693$ and $N_{C}=$ 452 for the three groups, a correct classification of $49.8 \%$ is still almost twice as high as a random allocation of samples (i.e., $\left.100 \mathrm{~N}_{\mathrm{C}} /\left(\mathrm{N}_{\mathrm{A}}+\mathrm{N}_{\mathrm{B}}+\mathrm{N}_{\mathrm{C}}\right)=25.6 \%\right)$. The discrimination of metamorphic garnets will be further evaluated and discussed in Section 5.1.

\subsection{Calculation of integrated probabilities}

Each step delivers some probabilities of belonging to the two or three simple or composite groups considered. It is thus finally necessary to integrate, for each garnet, all its estimated probabilities into a vector of 5 probabilities which sum to 1 and are consistent with all individual estimated values. This is achieved with a hierarchical approach, as graphically represented in Table 5. All these calculations are already prepared in the companion spreadsheet.

\subsection{Spreadsheet description and instructions of use}

The spreadsheet contains three kinds of sheets: (i) input/output (I/O) sheets, (ii) parameter sheets (pars_...), and (iii) internal calculation sheets (calc_...). The $\mathrm{I} / \mathrm{O}$ sheets are called 'priors' and 'data'. The sheet 'priors' should be used to control and eventually modify the values used to obtain the prior probabilities. As explained in Section 4.2, we provide some sensible default values for the prior probabilities (in grey cells, not to be modified!), but users are encouraged to adapt these values to their settings and experience by modifying the user choice columns (white and blue cells). The sheet 'priors' should be looked at first because it contains some further instructions.

The sheet "data" is expected to contain as input the compositions in wt.\% of $\mathrm{Cr}_{2} \mathrm{O}_{3}, \mathrm{MgO}$, $\mathrm{CaO}, \mathrm{FeO}, \mathrm{MnO}, \mathrm{Al}_{2} \mathrm{O}_{3}$ and $\mathrm{SiO}_{2}$ (in this order) between columns $\mathrm{B}$ and $\mathrm{H}$. If in some 
analyses $\mathrm{Cr}_{2} \mathrm{O}_{3}$ is not available or below detection limit, a zero can be placed in the corresponding cell. The rest of the values must be observed and cannot be zero. Zeros must be replaced by any sensible value before using the spreadsheet, for instance, by the detection limit (van den Boogaart and Tolosana-Delgado, 2013, pp. 209-253). Formulae in columns I to AA must be extended down to cover the number of samples. The same operation must be done for the sheets 'calc_LD1' (columns B to V), 'calc_LD2' (columns B to T) and 'calc_LD3' (columns $B$ to $X$ ). The final integrated probabilities can be found in columns V to $\mathrm{Z}$ from the sheet "data". Be aware that you will obtain misleading results if the formulae in all the 'calc_LD...' sheets have not been extended.

The sheet "data" contains in rows 3 to 6 as example four real garnet analyses taken from von Eynatten and Gaupp (1999). The first two analyses are distinctly classified with >95\% probabilities (when using prior 'global') to either group $B(H-1021-5,4)$ or $E(H-1021-5,5)$. Using the same prior, the other two analyses are less distinct, being classified between groups $B$ and $E(40$ vs. 59\%; H-1021-5, 10) and between groups A and C (45 vs. 53\%; EY214, 45). The next five examples (rows 7 to 11) are artificial compositions, derived from the medians of each variable for each group (art-1 to art-5). The reason why these compositions are not always assigned to their respective groups (e.g., only $1.2 \%$ D for art-1_D) is related to the prior (e.g., very low probability of $D$ in prior 'global') and will be discussed in Section 5.2. In general we suggest keeping these nine examples and starting with the data input in row 12.

The parameter sheets are 'pars_LD1', 'pars_LD2' and 'pars_LD3'. These contain the estimated parameters of the linear discriminant functions for each step, including the coefficients of the linear discriminant functions, the means of the explanatory variables for each group and links to the prior probabilities. Never edit these probabilities directly! Use the sheet 'priors' for that goal, otherwise you risk obtaining inconsistent results. With regard to pars_LD1, there is the option to modify the odds of having ultramafic garnet given that its $\mathrm{Cr}_{2} \mathrm{O}_{3}$ content is above or below the critical threshold of $200 \mathrm{ppm}$ (blue fields, 'enrichment factors'). 


\section{Discussion and evaluation}

\subsection{Discrimination of metamorphic garnets}

The results for metamorphic garnets as reported in Section 4.5 further underline the need for considering for each garnet a set of probabilities of classification instead of a sharp 'onecategory' classification. These probabilities, being three positive numbers $\left(p_{A}, p_{B}, p_{C} ;\right.$ Table 5) adding to $100 \%$ in case of discriminating metamorphic garnets (step 3), can be represented in ternary diagrams. This has been done for all major subgroups of garnets within the metamorphic facies groups, in order to evaluate if certain subgroups are more prone to be misclassified than others (Fig. 9). Eclogite-facies garnets (A) reveal an overall very high proportion ( $>90 \%$ ) of correctly classified samples, with both major subgroups $A 1$ (mafic metaigneous) and A5 (metaigneous UHP) yielding excellent results (94\% and 95\%, respectively). Amphibolite-facies garnets (B) reveal an overall reasonable result, with very high proportions of correct classified samples for the metasedimentary subgroups (B5 and $\mathrm{F} 1,89 \%$ and $100 \%$, respectively), while most (53\%) of the mafic metaigneous amphibolitefacies garnets (B1) are classified as eclogite (only 36\% correctly classified; Fig. 9). Although twice as good as random allocation, granulite-facies garnets (C) reveal the overall poorest result. This is especially valid for the mafic (C1) and felsic (C2) metaigneous granulites with $52 \%$ and $32 \%$ correctly classified garnets, respectively, while the metasedimentary granulites (C5) are reasonably well discriminated with $67 \%$ correctly classified samples (Fig. 9). Note that in this discrimination the prior is directly inferred from the size of the groups, e.g., 452/1767 for all granulite-facies garnets (C).

Interestingly, garnet from metasedimentary host rocks (F1, B5, C5, A6) allow for good to excellent discrimination through all metamorphic facies $(67 \%$ to $100 \%$ of correctly classified samples; Fig. 9). In contrast, problems arise with garnet from mafic metaigneous rocks, where especially eclogite and amphibolite facies (A1, B1, respectively) show considerable overlap. The latter has long been known (e.g., Mange and Morton, 2007) and is caused by 
several reasons, among them (i) similar protolith composition (e.g., basalt) limiting the potential contrast in garnet composition and (ii) problems in clearly distinguishing metamorphic grade of mafic metaigneous rocks at the amphibolite-eclogite facies transition, e.g., rocks appearing as garnet-bearing amphibolite may have suffered eclogite-facies metamorphism or vice versa, the exception being garnet grains with clear chemical zonation (e.g., Hauzenberger et al., 1996; Endo et al., 2013; see Section 5.3). Granulite-facies mafic (C1) and felsic (C2) metaigneous rocks appear rather similar with respect to garnet composition. Compared to the mafic metaigneous rocks of eclogite (A1) and amphibolite facies (B1) both subgroups $\mathrm{C} 1$ and $\mathrm{C} 2$ show some contrast (Fig. 9). Nevertheless, a considerable proportion of the metaigneous granulite-facies garnets is assigned to the eclogite facies (C1: 40\%; C2: 64\%), which appears unavoidable due to often similar garnet compositions (see Fig. 5 and Krippner et al., 2014).

\subsection{Influence and choice of prior}

In Section 4.2, we introduced the role of the prior in general and inferred a rough global estimate for relative proportions of garnet provenance (i.e., prior 'global'). The resulting prior probabilities for the major groups A, B, C, D, and E1 are 0.146, 0.458, 0.366, 0.003, and 0.026 (see spreadsheet, sheet 'priors', blue fields). Given that these values together with the discriminant function coefficients and the evidence obtained from each garnet composition are used to calculate the final probabilities of belonging to each of the groups, their influence is highly relevant. This is demonstrated, for instance, by the very low prior probability for ultramafic garnet in the prior 'global' $(0.27 \%)$, obviously because of rare global occurrence of such rocks compared to, e.g., metamorphic rocks. This causes the assignment of the "average" of group D garnets (art-1_D; see spreadsheet) to group C (79\%) instead of group D (1.2\%; Table 6). Another example, when using the prior 'global', results from the $\sim 2.5$ times higher prior probability of $\mathrm{C}$ relative to $\mathrm{A}$ : this leads to assigning the "average" of group $\mathrm{A}$ garnets (art3_A) to group C (52\%) instead of A (39\%; Table 6). If the prior between the two is equal, this sample would be assigned correctly to A ( 62-63\%; Table 6), consistent with the 
generally very high proportion of correctly classified samples for eclogite-facies garnets (Table 4, Fig. 9).

Considering the misclassification of the 'averages' of ultramafic and eclogitic garnets, an alternate prior is considered (prior 'equal'), which assigns the same prior probability to each type of garnet host rocks (i.e., 0.2 for A, B, C, D, and E1). Inserting these values as prior probabilities (blue fields, sheet 'prior') leads to the correct classification of all of the average compositions A to $\mathrm{E}$ with probabilities of $62 \%, 74 \%, 52 \%, 53 \%$, and $99 \%$, respectively (Table 6). This prior may be chosen, for instance, when the a priori knowledge is low (like for the prior 'global'), but each of the potential garnet host rock groups is considered to be equally possible.

Most studies in detrital garnet chemistry are related to metamorphic source rocks, and are typically interested in changes in metamorphic facies, for instance changes in the source area towards higher/lower degree of metamorphic overprint with time to infer geodynamic interpretations (e.g., Win et al., 2007a; Andò et al., 2014; see also Section 5.4). In such case, one may prefer to set equal prior probabilities for all metamorphic facies, but significantly lower probabilities for the other groups. We therefore introduce the prior 'equal- $M$ ', which considers equal probability of belonging to the three major garnet-bearing metamorphic facies, and much lower but similar probability for ultramafic (D) and felsic plutonic rocks (E). The prior probabilities for the major groups A, B, C, D, and E1 are thus $0.3,0.3,0.3,0.05$, 0.05 , respectively. This leads to a correct classification of all of the average compositions except for ultramafic garnets (art1_D) (see Table 6 and spreadsheet).

\subsection{Evaluation of garnets from crystalline rocks}

Several examples of garnet composition from the various host-rock and metamorphic facies types from different settings have been chosen for evaluation of the discrimination scheme. For each example the classification results are given for the three priors introduced before (Table 7). 
The first test case among the eclogite-facies examples (A-a; Table 7) represents a large suite of eclogite xenolithes from kimberlite pipes of the Slave craton, Canada (Kopylova et al., 2016). Due to generally high $\mathrm{Mg}$ and $\mathrm{Ca}$ content relative to low $\mathrm{Fe}$ and $\mathrm{Mn}$ content $>90 \%$ of the garnets are correctly assigned to the eclogite-facies group (A). Only if the prior 'global' is used, which assigns to this group a 2.5 to 3 times lower prior probability compared to groups $\mathrm{B}$ and $\mathrm{C}$, the proportion of correctly classified garnets is somewhat lower but still at $70 \%$ (Table 7). The second example is an ultra-high pressure (UHP) eclogite from Flatraket from one of the UHP domains in the Western Gneiss Region of Norway (A-a; Table 7; Krippner et al., 2016). Garnets from this sample are correctly assigned with $>90 \%$ to the eclogite-facies group when using the priors with equal probability for all metamorphic garnets ('equal' and 'equal-M'). When using the prior global, the assignment changes completely to $>90 \%$ granulite facies $(\mathrm{C})$. This example demonstrates that (i) the decision between the metamorphic-facies groups and especially between eclogite and granulite are delicate due to the strong overlap in compositions (see above and Fig. 5) and (ii) in this situation the choice of the prior is very crucial (Fig. 10A). A roughly similar result is documented by two further eclogite examples, one from Runde in the Western Gneiss Region (A-c; Table 7) and one from the western Tauern window (central Eastern Alps, Austria) (A-d). Both samples are correctly classified with $>90 \%$ and $>70 \%$, respectively, when using the two priors with equal probability for metamorphic garnets (Table 7).

The first among the amphibolite-facies examples (B-a; Table 7) represents garnet compositions from garnet mica schists from the Tongbai section of the Shangdan Fault Zone in Central China that experienced epidote-amphibolite to amphibolite-facies metamorphism at $\sim 560$ to $620^{\circ} \mathrm{C}$ and 0.8 to $1.0 \mathrm{GPa}$ (Ren et al., 2015). According to our discrimination scheme, these garnets are assigned correctly at $100 \%$ to the amphibolite-facies group (B), independent of the prior used (Table 7). Moreover, the correct assignment has high percentages of probability ( $\geq 65 \%$ ), and is highest in case of the prior 'global' (80-99\%). A second test example (B-b) is a mica schist sample from the boundary between the Eclogite Zone and the Upper Schieferhülle (Glockner nappe) in the western Tauern window (central 
Eastern Alps, Austria), which experienced amphibolite- to blueschist-facies metamorphism (B-b, Table 7). This sample also shows entirely correct assignment to the amphibolite-facies group (B) with high individual percentages of probability (66-98\%). The third example (B-c) is garnet from mica schist surrounding the Dehnow Pluton in NE Iran (Samadi et al., 2014). These schists experienced amphibolite-facies metamorphism at around $570^{\circ} \mathrm{C}$ and $5.3 \mathrm{kbar}$ (Samadi et al., 2012) and their garnets are assigned correctly to amphibolite facies for 95\% of the analyses (Table 7). Using the prior 'equal' reduces correct assignment to $64 \%$ while assignment to plutonic rock increases to $36 \%$. This is because of the much higher prior probability for group $\mathrm{E}$, which leads to assigning garnet with higher $\mathrm{MnO}$ content ( $4 \mathrm{wt} . \%)$ to plutonic rocks $(E)$ when using the prior 'equal'. The next example (B-d) is garnet from amphibolites from the Nagaland Ophiolite Complex in India, which experienced peak metamorphism between amphibolite and hornblende eclogite facies $\left(\sim 625^{\circ} \mathrm{C}, 13-14 \mathrm{kbar}\right)$ followed by blueschist- to greenschist-facies overprint (Bhowmik and Ao, 2016). Most of these garnets are correctly assigned to amphibolite facies, however, about one third is assigned to plutonic rocks (Table 7). This is because of high $\mathrm{MnO}$ content in excess of 20 wt.\% and thus very high $\mathrm{MnO} / \mathrm{FeO}$ ratios in some of these garnets, which independently of the prior used leads to group E assignment (Figs. 4, 8, LD2).

The first among the granulite-facies examples ( $\mathrm{C}-\mathrm{a}$; Table 7$)$ represents garnet from various granulite-facies rocks (schists, gneisses, granofelses and migmatites) from the southern Appalachian orogen (North Carolina, U.S.A.) with peak metamorphic conditions around $850^{\circ} \mathrm{C}$ and $9 \mathrm{kbar}$ (El Shazly et al., 2011). Interestingly, all garnet from metapelitic schists and gneisses is incorrectly assigned to amphibolite facies, while 8 out of 11 (73\%) garnets from garnet-hornblende-biotite granofelses and from leucosomes are correctly assigned to granulite facies. Two further examples (C-b, C-c) from metasedimentary granulites with roughly similar peak pressure and temperature conditions from East Antarctica (Prydz Belt; Tong et al., 2014) and Northern Madagascar (Buchwaldt et al., 2003) reveal better results with 75 and 55\% correctly classified samples, respectively, when using the two priors with equal probability for metamorphic garnets (Table 7). These moderate 
results (as compared to the results for amphibolite- and eclogite-facies rocks) in fact corroborate the results obtained from the database itself (see Sections 4.5 and 5.1). The fourth example (C-d) derives from garnet-bearing ultra-high temperature (UHT) granulite from the Inner Mongolia Suture Zone in the North China Craton where garnet formed after peak metamorphic conditions at 975 to $875^{\circ} \mathrm{C}$ and $\sim 8 \mathrm{kbar}$ (Zhang et al., 2012a). These garnets show $100 \%$ correct assignment to granulite facies with high proportions of individual probabilities (73-89\%). The last granulite-facies example (C-e) is garnet from a felsic granulite from Flatraket (Western Gneiss Region, Norway), which is assigned to eclogite facies independent of the prior used (Table 7). The Flatraket area is dominated by massive granulite of quartz-monzonitic composition, which is locally (towards its margins) overprinted by amphibolite- to eclogite-facies metamorphism (Wain et al., 2001). Sample AK-N11 comes from the NE margin of Flatraket Peninsula where several eclogite lenses have been mapped (Krabbendam et al., 2000), and the new garnet results may reflect a hitherto underestimated eclogite-facies overprint of the area. Moreover, as discussed in Section 5.1, garnet from metaigneous granulite (especially felsic ones; see C2 in Fig. 9) tend to be assigned to eclogite facies due to strong overlap in garnet composition (Fig. 5). Sample AK-N11 exactly plots into the area of strongest overlap between granulite and eclogite facies (Krippner et al. 2016).

The examples for garnet from ultramafic rocks (D) reveal very good to perfect results (67$100 \%$ correctly classified garnets) if the prior 'equal' is used (Table 7). With prior 'equal-M' three out of four examples are still classified correctly by $78-100 \%$, but one example (D-b) is assigned to granulite-facies rocks. This is due to comparatively low $\mathrm{Cr}_{2} \mathrm{O}_{3}$ content and rather high $\mathrm{Al}_{2} \mathrm{O}_{3} / \mathrm{SiO}_{2}$ ratio for these garnets, which derive from orthopyroxenite veins representing metasomatic products between the wall dunites (see example D-a that is correctly classified; Table 7) and silica-rich hydrous melts under UHP metamorphic conditions (Chen et al., 2017). Using the prior 'global' all ultramafic examples failed, which is obviously due to the very low prior probability for $\mathrm{D}$. Together with the discussion of priors in Section 5.2 these 
examples clearly suggest that the prior 'global' is inappropriate when ultramafic rocks are considered as possible source of the investigated garnets.

Felsic plutonic rocks $(\mathrm{E})$ of different composition and geodynamic setting have been tested and the results are very good to perfect (73-100\% correctly classified garnets) for three out of five examples (E-a to E-c; Table 7). The other two examples are S-type granites; garnets from such rocks are well-known for complex histories because they (i) may have formed as magmatic or peritectic crystals in the presence of corresponding melt, or (ii) may constitute restitic remnants from digested source materials reflecting the metamorphic conditions under which the source rocks of the S-type granite were formed (e.g., Villaros et al., 2009). The two S-type granite examples E-d and E-e (Table 7) most likely represents the two cases (i) and (ii), respectively. Example E-d reveals garnet formed by direct crystallization from peraluminous magma in equilibrium with solid phases such as biotite and white mica (Dahlquist et al., 2007); these are assigned correctly to group $E$ if using prior 'equal' (92\%; Table 7). Assignment to $E$ is strongly reduced when using priors with lower probability for $\mathrm{E}$ because of pronounced Mn-zoning in the magmatic garnets (Dahlquist et al., 2007), i.e., Mn-rich rims are still assigned to $E$, but Mn-poorer cores are assigned to $B$. This example again highlights the high relevance of a well-justified choice of prior (Fig. 10B). Example E-e, in contrast, shows garnet from S-type granite which is mostly assigned to group B (amphibolite facies) independent of the prior used (76-88\%; Table 7). This, however, makes sense because the garnets are interpreted to be refractory residues from partial melting in the deep crust (Jung et al., 2001).

\subsection{Evaluation of detrital garnets}

Because this contribution is primarily designed for sedimentary provenance analysis, we finally want to evaluate the consistency of the proposed discrimination scheme with examples from the literature, among them well-defined multi-method provenance studies. Because (i) the previous evaluations have revealed the overall best results for priors 'equal 
and 'equal-M', and (ii) the detrital examples focus on metamorphic source rocks, we will use the prior 'equal-M' throughout.

The first example deals with two gneiss pebbles collected at the mouth of a small creek at the north coast of the Flatraket Peninsula, Western Gneiss Region (Norway). The creek drains mostly amphibolite-facies rocks with some higher grade felsic gneisses and locally lenses of ultramafic rocks and eclogites (Krabbendam et al., 2000; Krippner et al., 2016). One pebble (S-a) is a strongly foliated biotite rich, epidote and amphibole bearing, garnetpoor gneiss, which is clearly assigned to the amphibolite facies B (100\% and $88 \%$; Table 8$)$, independent of the prior used. The other pebble (S-b) is a weakly foliated quartz, plagioclase and garnet rich felsic gneiss, which is assigned to the granulite facies C. In fact, $95 \%$ of all garnets are assigned to $\mathrm{C}$ using the highest probability for each individual grain. The averaged integrated probabilities for all grains support this classification (54\%C; Table 8$)$. This example provides clear assignment of two gneiss pebbles to distinct metamorphic facies consistent with macroscopic inspection, reflecting two of the most common metamorphic facies in the respective drainage area.

Because sand-sized sediment may be considered to reflect the entire spectrum of lithologies in the hinterland better than pebbles, we have evaluated a modern sand sample from a well-defined catchment of the Ulvesund Peninsula (S-C; adjacent to the previous example at Flatraket), which is entirely composed of granulites with eclogite lenses (the amount of the latter, however, is not well known). The majority of garnets is assigned to the granulite facies (58\%), the rest mostly to the eclogite facies (38\%). The averaged integrated probabilities indicate $57 \%$ for group C (Table 8 ). This example underlines that detrital garnet provides a good image of the geology of the drainage basin. Especially the low probability for garnet from amphibolite facies nicely fits to the mapped geologic situation (Krabbendam et al., 2000; Krippner et al., 2016).

In an example from a well-defined multi-method provenance study we compare garnet from two contrasting source areas (S-d; Table 8), inferred from a multi-method analysis of Cretaceous sediments in the Eastern Alps of Europe (von Eynatten and Gaupp, 1999). The 
northwestern source area was located at the transpressive plate margin between the Austroalpine microplate and the Penninic Ocean during the early Alpine orogeny, the southeastern source area was located at the southeastern margin of the Austroalpine microplate, overthrusted by continental rocks from Tisza/Southalpine Units and remnants of the Vardar/Meliata suture zone. Both source areas delivered detritus derived from sedimentary rocks, serpentinites, and low- to medium-grade metamorphic rocks. The main contrast between the source areas is the contribution of high-pressure rocks from the northwestern source as witnessed by blue sodic amphibole and phengitic mica. This is supported by a higher proportion of garnet with both pyrope and grossular components $>10 \%$, which has been interpreted to derive from amphibolites and/or blueschist-associated eclogites (von Eynatten and Gaupp, 1999). Using the new classification scheme (prior 'equal-M'), the previous results are corroborated: $24 \%$ of garnet from the northwestern source area is assigned to the eclogite-facies group compared to only $12 \%$ for the southeastern source area; the increase in eclogite-facies garnet is mainly compensated by decrease in amphibolite-facies garnet (Table 8). Similarly, the averaged integrated probabilities for each source area support an about 2 to 2.5 times higher contribution of group-A garnets from the northwestern source (Table 8; Fig. 11A).

For a further example of a well-defined multi-method provenance study we have chosen Miocene to Pleistocene sediments from the East African Rift System (Albertine Rift, Uganda; Schneider et al., 2016) (S-e; Table 8). The study area is located at the southern end of Lake Albert. Sediment provenance reflects the transition from northeastern sources, mainly composed of Archean high-grade granulite-facies rocks, to southern sources, mainly composed of low- to medium-grade metasedimentary rocks. In fact, the evolution from Middle Miocene to Lower Pleistocene has been subdivided into three stages: (1) pre-rift stage, NE to SW trending low-relief sediment supply system (Middle to Upper Miocene); (2) syn-rift stage, variable sediment supply from medium to high-grade metamorphic rocks from the uplifted rift shoulder in the southeast (Pliocene); (3) roughly $S$ to $N$ trending sediment supply from low- to medium-grade metasedimentary rocks of the uplifted Rwenzori 
Mountains within the Albertine Rift (Pleistocene; Schneider et al., 2016). This evolution is nicely reflected by the detrital garnet chemistry data: While Miocene garnets (Kisegi and Oluka Fm., S-e, Table 8) are dominated by granulite-facies type C, Pliocene garnets are roughly equally composed of medium- $(B)$ and high-grade $(A, C)$ metamorphic garnets (Nyaburogo Fm., S-e, Table 8). In the Lower Pleistocene, low- to medium-grade garnets along with a high proportion of garnets classified as felsic plutonic are predominant (Nyaburosi Fm., S-e, Table 8). The latter are characterized by high MnO contents up to 27 wt.\% that defines felsic plutonic provenance according to the new discrimination scheme. However, such high-MnO garnets may also occur in low-medium grade metasedimentary rocks (e.g., Theye et al., 1996). If type $\mathrm{E}$ is considered unlikely, these garnets are almost exclusively assigned to $B$ according to the calculated integrated probabilities. The described trend of the three stages is convincingly illustrated by a ternary diagram of integrated probabilities of the three metamorphic facies types $A B C$, independent of using $B$ separately or amalgamated with $\mathrm{E}$ (Fig. 11B).

\section{Conclusions and outlook}

The proposed multivariate discrimination scheme for garnet geochemistry is built on a large database $(\mathrm{N}=3188)$, a hierarchical discrimination approach involving three steps, and the five major host-rock groups to be discriminated: eclogite- $(A)$, amphibolite- $(B)$ and granulite(C) facies metamorphic rocks as well as ultramafic (D) and igneous rocks (E). The discrimination technique relies on linear discriminant analysis with cross validation and prior probabilities to be chosen by the user depending on the specific geologic situation. Cross validation results are very good at the first two discrimination steps (D vs. ABCE, 97\%; E vs. $A B C, 94 \%$ ) and reasonable at the third step (A vs. B. vs. C, 74\%). The discrimination results are provided as integrated probabilities of belonging to the five major host-rock groups. All calculations and results can be obtained from a supplementary Excel® spreadsheet. 
Three priors (i.e., sets of prior probabilities) are introduced based on the following considerations: (i) given the lack of any geologic a priori information we have roughly estimated the proportional exposure and garnet content of garnet-bearing host rocks at the earth surface at global scale (prior 'global'), (ii) equal prior probability for each type of garnet host rock (prior 'equal'), and (iii) equal prior probabilities for all metamorphic facies, but significantly lower probabilities for ultramafic and plutonic rocks (prior 'equal-M'). The user is free to choose among these priors, which can be further modified according to the specific geologic problem and the level of a priori knowledge. Reporting results obtained by the proposed method essentially requires indication of the respective prior used for calculations.

The discrimination scheme has been tested for a large variety of examples of crystalline rocks (22 cases with in total 753 garnet analyses) covering all of the five major groups and several subgroups. In most cases garnets are assigned correctly to the respective group; exceptions can be readily explained by the regional geologic situation. Evaluations of 630 detrital garnets from several modern and ancient sedimentary settings from the Western Gneiss Region (Norway), Eastern Alps (Austria) and Albertine Rift (Uganda) strongly reflect the respective geologic situations and corroborate previous results.

The new approach provides probabilities of belonging to the five major host-rock groups rather than more or less overlapping discrimination fields without the possibility to quantify uncertainty. It thus accounts for the obvious fact that a perfect discrimination of garnet is impossible, given the complex control on garnet composition and well-known overlap in the composition of garnet from different settings. With respect to metamorphic garnet the approach emphasizes discrimination of metamorphic facies (i.e., temperature-pressure conditions) rather than protolith composition. Given that many provenance studies aim at reconstructing tectonic and geodynamic evolution in the source area, such focus appears justified.

Further research is necessary to optimise the proposed garnet discrimination scheme, including further enlargement and improvement of the database, applications to zoned garnets along with the distinction of prograde and retrograde metamorphic evolution. 
Suchsophisticated classification should also involve specific garnet-bearing rock types such as calc-silicate rocks (e.g. skarn) or some mafic volcanics, specific garnet types such as Tirich but Cr-poor varieties, and the discrimination of greenschist-facies rocks. We invite the community to share with us their experience, data, and problems with the new discrimination scheme in order to further improve this specific tool as well as quantitative discrimination of sediments and minerals in general.

\section{Acknowledgements}

The PhD scholarship of AK was financed by CASP. Fieldwork and analytical work, which laid the foundation for the database and several examples used in this study, was financed by the German Research Foundation (DFG grant EY 23/20-1). We thank Eva Russell and Jan Schönig for their help with sample preparation and analysis, and István Dunkl and Andrew Morton for stimulating scientific discussions. Careful reviews by Abhijit Basu and Sergio Andò greatly helped improving the manuscript.

\section{References}

Aitchison, J., 1986. The Statistical Analysis of Compositional Data. Monographs on Statistics and Applied Probability. Chapman \& Hall Ltd., London (Reprinted in 2003 with additional material by The Blackburn Press), $416 \mathrm{pp}$.

Andò, S., Morton, A.C., Garzanti, E., 2014. Metamorphic grade of source rocks revealed by chemical fingerprints of detrital amphibole and garnet. In: Scott, R.A., Smyth, H.R., Morton, A.C., Richardson, N. (Eds.), Sediment Provenance Studies in Hydrocarbon Exploration and Production. Geological Society London, Special Publication, 386, pp. 395-412.

Aubrecht, R., Méres, Š., Sýkora, M., Mikus, T., 2009. Provenance of the detrital garnets and spinels from the Albian sediments of the Czorsztyn Unit (Pieniny Klippen Belt, Western Carpathians, Slovakia). Geologica Carpathica 60, 463-483. 
Bhowmik, S.K., Ao, A., 2016. Subduction initiation in the Neo-Tethys: constraints from counterclockwise P-T paths in amphibolite rocks of the Nagaland Ophiolite Complex, India. Journal of Metamorphic Geology 34, 17-44.

Bucher, K., Frey, M., 1994. Petrogenesis of Metamorphic Rocks. Springer-Verlag, Berlin, 318 pp.

Buchwaldt, R., Tucker, R.D., Dymek, R.F., 2003. Geothermobarometry and U-Pb Geochronology of metapelitic granulites and pelitic migmatites from the Lokoho region, Northern Madagascar. American Mineralogist 88, 1753-1768.

Chen, Y., Su, B., Chu, Z., 2017. Modification of an ancient subcontinental lithospheric mantle by continental subduction: Insight from the Maowu garnet peridotites in the Dabie UHP belt, eastern China. Lithos 278-281, 54-71.

Dahlquist, J.A., Galindo, C., Pankhurst, R.J., Rapela, C.W., Alasino, P.H., Saavedra, J., Fanning, C.M., 2007. Magmatic evolution of the Peñón Rosado granite: Petrogenesis of garnet-bearing granitoids. Lithos 95, 177-207.

Dürr, H.H., Meybeck, M., Dürr, S.H., 2005. Lithologic composition of the Earth's continental surfaces derived from a new digital map emphasizing riverine material transfer. Global Biogeochemical Cycles, 19, 4, GBS4S10.

El-Shazly, A.K., Loehn, C., Tracy, R.J., 2011. P-T-t evolution of granulite facies metamorphism and partial melting in the Winding Stair Gap, Central Blue Ridge, North Carolina, USA. Journal of Metamorphic Geology 29, 753-780.

Endo, S., Nowak, I., Wallis, S.R., 2013. High-pressure garnet amphibolite from the Funaokayama unit, western Kii Peninsula and the extent of eclogite facies metamorphism in the Sanbagawa belt. Journal of Mineralogical and Petrological Sciences 108, 189-200.

Fahrmeir, L., Hammerle, A., 1984. Multivariate Statistische Verfahren. Walter de Gruijter Verlag, Berlin, 796 pp. 
Garzanti, E., Andò, S., 2007. Heavy mineral concentration in modern sands: implications for provenance interpretation. In: Mange, M.A., Wright, D.T. (Eds.), Heavy Mineral in Use. Developments in Sedimentology 58, pp. 517-545.

Grew, E.S., Locock, A.J., Mills, S.J., Galuskina, I.O., Galuskina, E.V., Hålenius, U., 2013. Nomenclature of the garnet supergroup. American Mineralogist 98, 785-811.

Grütter, H.S., Gurney, J.J., Menzies, A.H., Winter, F., 2004. An updated classification scheme for mantle-derived garnets, for use by diamond explorers. Lithos 77, 841-857. Hauzenberger, C.A., Höller, W., Hoinkes, G., 1996. Transition from eclogite to amphibolitefacies metamorphism in the Austroalpine Ulten Zone. Mineralogy and Petrology 58, $111-130$.

Johnsson, M.J. 1993. The system controlling the composition of clastic sediments. In: Johnsson, M.J., Basu, A. (Eds.), Processes Controlling the Composition of Clastic Sediments. Geological Society of America, Special Papers, 284, pp. 1-19.

Jung, S., Mezger, K., Hoernes, S., 2001. Trace element and isotopic (Sr, Nd, Pb, O) arguments for a mid-crustal origin of Pan-African garnet-bearing S-type granites from the Damara orogen (Namibia). Precambrian Research 110, 325-355.

Kopylova, M.G., Beausoleil, Y., Goncharov, A., Burgess, J., Strand, P., 2016. Spatial distribution of eclogite in the Slave cratonic mantle: The role of subduction. Tectonophysics 672-673, 87-103.

Krabbendam, M., Wain, A., Andersen, T.B., 2000. Pre-Caledonian granulite and gabbro enclaves in the Western Gneiss Region, Norway: indications of incomplete transition at high pressure. Geological Magazine 137, 235-255.

Krippner, A., Meinhold, G., Morton, A.C., von Eynatten, H., 2014. Evaluation of garnet discrimination diagrams using geochemical data of garnets derived from various host rocks. Sedimentary Geology 306, 36-52.

Krippner, A., Meinhold, G., Morton, A.C., Russell, E., von Eynatten, H. 2015. Grain-size dependence of garnet composition revealed by provenance signatures of modern 
stream sediments from the western Hohe Tauern (Austria). Sedimentary Geology 321, 25-38.

Krippner, A., Meinhold, G., Morton, A.C., von Eynatten, H., 2016. Heavy-mineral and garnet compositions of stream sediments and HP-UHP basement rocks from the Western Gneiss Region, SW Norway. Norwegian Journal of Geology 9, 7-17.

Lock, N.P., Dawson, J.B., 1980. Garnet-olivine reaction in the upper mantle: evidence from peridotite xenoliths in the Letseng-la-Terae kimberlites, Lesotho. Transactions of the Royal Society of Edinburgh: Earth Sciences 71, 47-53.

Mange, M.A., Morton, A.C., 2007. Geochemistry of heavy minerals. In: Mange, M.A., Wright, D.T. (Eds.), Heavy Minerals in Use. Developments in Sedimentology 58, pp. 345-391.

Miller, C.F., Stoddard, E.F., 1981. The role of manganese in the paragenesis of magmatic garnet: an example from the Old Woman-Piute Range, California. Journal of Geology 89, 233-246.

Moecher, D.P., Samson, S.D., 2006. Differential zircon fertility of source terranes and natural bias in the detrital zircon record: Implications for sedimentary provenance analysis. Earth and Planetary Science Letters 247, 252-266.

Morton, A.C., 1985. A new approach to provenance studies: electron microprobe analysis of detrital garnets from Middle Jurassic sandstones of the northern North Sea. Sedimentology 32, 553-566.

Morton, A., Hallsworth, C., 2007. Stability of detrital heavy minerals during burial diagenesis. In: Mange, M.A., Wright, D.T. (Eds.), Heavy Minerals in Use. Developments in Sedimentology 58, pp. 215-245.

Morton, A., Hallsworth, C., Chalton, B., 2004. Garnet compositions in Scottish and Norwegian basement terrains: a framework for interpretation of North Sea sandstone provenance. Marine and Petroleum Geology 21, 393-410.

Nandi, K., 1967. Garnets as indices of progressive regional metamorphism. Mineralogical Magazine 36, 89-93. 
R core team, 2012. R: A language and environment for statistical computing. R Foundation for Statistical Computing, Vienna, Austria. http://www.R-project.org/.

Ren, S., Song, C., Li, J., 2015. Mineralogical characteristics of garnet in garnet mica schist and its tectonic significance in the Tongbai section of the Shangdan fault zone. Open Journal of Geology 5, 13-27.

Riebe, C.S., Sklar, L.S., Lukens, C.E., Shuster, D.L., 2015. Climate and topography control the size and flux of sediment produced on steep mountain slopes. Proceedings of the National Academy of Sciences 112, 15574-15579.

Samadi, R., Valizadeh, M.V., Mirnejad, H., Kawabata, H., 2012. Geothermometry and geobarometry of metamorphic rocks of Dehnow (Northwest of Mashhad). Geosciences Scientific Quarterly Journal, 21 (84), 3-14.

Samadi, R., Mirnejad, H., Kawabata, H., Harris, C., Valizadeh, M.V., Gazel, E., 2014. Magmatic garnet in the Triassic (215 Ma) Dehnow pluton of NE Iran and its petrogenetic significance. International Geology Review 56, 596-621.

Skinner, C.P., 1989. The petrology of peridotite xenoliths front the Finsch kimberlite, South Africa. South African Journal of Geology 92, 197-206.

Stutenbecker, L., Berger, A., Schlunegger, F., 2017. The potential of detrital garnet as a provenance proxy in the Central Swiss Alps. Sedimentary Geology 351, 11-20.

Suggate, S.M., Hall, R., 2014. Using detrital garnet compositions to determine provenance: a new compositional database and procedure. In: Scott, R.A., Smyth, H.R., Morton, A.C., Richardson, N. (Eds.), Sediment provenance studies in hydrocarbon exploration and production. Geological Society of London, Special Publications, 386, pp. 373-393.

Theye, T., Schreyer, W., Fransolet, A.-M., 1996. Low-temperature, low-pressure metamorphism of Mn-rich rocks in the Lienne Syncline, Venn-Stavelot Massif (Belgian Ardennes), and the role of carpholite. Journal of Petrology 37, 767-783.

Tolosana-Delgado, R., 2012. Uses and misuses of compositional data in Sedimentology. Sedimentary Geology 280, 60-79. 
Tong, L., Liu, X., Wang, Y., Liang, X., 2014. Metamorphic P-T paths of metapelitic granulites from the Larsemann Hills, East Antarctica. Lithos 192-195, 102-115.

van den Boogaart, G., Tolosana-Delgado, R., 2013. Analyzing compositional data with R. Use R! series, Springer, Heidelberg, 258 pp.

Venables, W.N., Ripley, B.D, 2002. Modern Applied Statistics with S. Fourth Edition. Springer, New York, 495 pp.

Villaros, A., Stevens, G., Buick, I.S., 2009. Tracking S-type granite from source to emplacement: Clues from garnet in the Cape Granite Suite. Lithos 112, 217-235.

von Eynatten, H., Gaupp, R., 1999. Provenance of Cretaceous synorogenic sandstones in the Eastern Alps: constraints from framework petrography, heavy mineral analysis and mineral chemistry. Sedimentary Geology 124, 81-111.

von Eynatten, H., Dunkl, I., 2012. Assessing the sediment factory: the role of single grain analysis. Earth Science Reviews 115, 97-120.

von Eynatten, H., Barceló-Vidal, C., Pawlowsky-Glahn, V., 2003. Sandstone composition and discrimination: a statistical evaluation of different analytical methods. Journal of Sedimentary Research, 73, 47-57.

Wain, A.L., Waters, D.J., Austrheim, H., 2001. Metastability of granulites and processes of eclogitisation in the UHP region of western Norway. Journal of Metamorphic Geology, 19, 609-625.

Wang, R., Hu, H., Zhang, A., Xu, S., Wang, D., 2003. Yttrium zoning in garnet from the Xihuashan granitic complex and its petrological implications. Chinese Science Bulletin $48,1611-1615$.

Win, K.S., Takeuchi, M., Tokiwa, T., 2007a. Changes in detrital garnet assemblages related to transpressive uplifting associated with strike-slip faulting: An example from the Cretaceous System in Kii Peninsula, Southwest Japan. Sedimentary Geology 201, $412-431$. 
Win, K.S., Takeuchi, M., Iwakiri, S., Tokiwa, T., 2007b. Provenance of detrital garnets from the Yukawa Formation, Yanase district, Shimanto belt, Kii Peninsula, Southwest Japan. Journal of the Geological Society of Japan 113, 133-145.

Wright, W.I., 1938. The composition and occurrence of garnets. American Mineralogist, 23, 436-449.

Wu, F.-y., Sun, D.-y., Jahn, B.-m., Wilde, S., 2004. A Jurassic garnet-bearing granitic pluton from NE China showing tetrad REE patterns. Journal of Asian Earth Sciences 23, 731744.

Zhang, H., Li, J., Liu, S., Li, W., Santosh, M., Wang, H., 2012a. Spinel + quartz-bearing ultrahigh-temperature granulites from Xumayao, Inner Mongolia Suture Zone, North China Craton: Petrology, phase equilibria and counterclockwise p-T path. Geoscience Frontiers 3, 603-611.

Zhang, J., Ma, C., She, Z., 2012b. An Early Cretaceous garnet-bearing metaluminous A-type granite intrusion in the East Qinling Orogen, central China: Petrological, mineralogical and geochemical constraints. Geoscience Frontiers 3, 635-646.

\section{Figure captions}

Fig. 1. Biplots of garnet composition according to the major host-rock groups $A$ to $E$, with indication of percentages of explained variability for each principal component (A: PC1 vs. PC2; B: PC3 vs. PC4). Individual variabilities sum up to $>99 \%$.

Fig. 2. Frequencies of occurrence of garnets with low ( $\leq 200 \mathrm{ppm})$ and higher $\mathrm{Cr}_{2} \mathrm{O}_{3}$ content in ultramafic rocks ( $D$, blue) vs. all other rock types (ABCE, grey).

Fig. 3. (A) Probability densities and boxplots of the logratio $\mathrm{MgO} / \mathrm{FeO}$ for garnets from rock type $D$ (ultramafic, blue) against garnets from all other rock types (ABCE, grey). (B) Crossplot of $\mathrm{Cr}_{2} \mathrm{O}_{3}$ content vs. logratio $\mathrm{MgO} / \mathrm{FeO}$ to illustrate the benefit of using both parameters for discrimination. Stippled line indicate 200 ppm threshold for $\mathrm{Cr}_{2} \mathrm{O}_{3}$. 
Fig. 4: Probability densities and boxplots of the logratio $\mathrm{MnO} / \mathrm{FeO}$ for garnets from rock type E1 (felsic plutonic, green) against garnets from all metamorphic rock types (ABC, brown).

Fig. 5. Classification diagram for metamorphic garnets according to Mange and Morton (2007). Plotted are all metamorphic garnets from the database, i.e., from eclogitefacies rocks $(A)$, amphibolite-facies rocks $(B)$ and granulite-facies rocks $(C)$. Note that garnets from non-metamorphic origin are not included. Inset highlights original classification by Mange and Morton (2007) with fields A (granulite-facies metasediments), B (amphibolite-facies metasediments: $\mathrm{Bi}+\mathrm{Bii}$; intermediate to acidic igneous rocks: exclusively $\mathrm{Bi}$ ), $\mathrm{Ci}$ (high-grade metamafic rocks), Cii (ultramafic rocks), D (metasomatic rocks and others).

Fig. 6. Hierarchical strategy of garnet classification, with indication of colours used throughout this paper and sample size for each rock type.

Fig. 7. Probability densities and boxplots of the scores of the linear discriminant function for garnets from rock type $D$ (ultramafic, blue) against garnets from all other rock types (ABCE, grey); only garnet with $\mathrm{Cr}_{2} \mathrm{O}_{3}>200$ ppm was considered.

Fig. 8. Probability densities and boxplots of the scores of the linear discriminant function for garnets from E1 (acid plutonics, green) against those from metamorphic rock types together (ABC, brown).

Fig. 9. Ternary diagrams of the probabilities $\left(p_{A}, p_{B}, p_{C}\right)$ obtained for the most relevant subgroups of metamorphic garnets (coloured circles), compared to the whole 
metamorphic samples (light grey dots, $\mathrm{N}=1767$ ). For each subgroup the number of samples (Table 1) and the percentage of correctly classified samples are indicated.

Fig. 10. Ternary diagrams of the probabilities obtained for the three relevant host-rock groups for two examples from Table 7 to illustrate the effect of the prior. (A) Example A-b (UHP eclogite) which is assigned correctly (91\%) to group A when using priors with equal probabilities for metamorphic rocks ('equal' and 'equal-M'). Because these priors have exactly the same ratios between groups $A, B$, and $C$, the calculated probabilities are the same (i.e., red and blue symbols overlap). In contrast, using the prior 'global' with 2.5 times higher probability for group $C$ compared to $A$, the garnets are assigned to group C. (B) Example E-d (S-type granite) is assigned correctly to group $E$ (92\%) when using prior 'equal', but with higher proportions to group B when using priors with lower probability for group E like 'equal-M' and especially 'global' (see also Table 7).

Fig. 11. Ternary diagrams of the probabilities obtained for two detrital garnet examples from Table 8. (A) Example S-d (Eastern Alps) is dominated by amphibolite-facies (group B) garnets but reveals a subtle increase of high-pressure (group A) garnets for the NW source, which is reflected by both number of garnets assigned to $A$ and the respective means. (B) Example S-e (Albertine Rift) shows a major change from Miocene formations (Kisegi, Oluka) dominated by granulite-facies garnets (group C) via Pliocene (Nyaburogo Fm.; roughly equal proportions of B vs. $A+C$ ) to Pleistocene (Nyaburosi Fm.), the latter being dominated by low- to medium-grade garnets (group B). If groups $B$ and $E$ are amalgamated (left triangle) minor changes are observed, but the overall pattern is very similar. See text for further explanations and references.

\section{Tables}


Table 1. List auf major groups and subgroups of garnet host rocks and corresponding number of analyses. Subgroups E2 to E4 (in italics) are not included in the final database (see text).

Table 2. Cross-validation results for the two-way discrimination of ultramafic garnets $(D)$ from the rest, i.e., including all garnet independent of $\mathrm{Cr}_{2} \mathrm{O}_{3}$ content.

Table 3. Cross-validation results for the discrimination of felsic plutonic garnets (E1) from garnets from metamorphic rocks $(A B C)$.

Table 4. Cross-validation results for the discrimination of the different metamorphic facies ( $A$ vs. B vs. C)

Table 5. Graphical representation of the approach to derive integrated probabilities from the probabilities estimated at each of the three discrimination steps.

Table 6. Probabilities of belonging to the respective host rock/facies groups for the 'averages" of each group A to E (see text and spreadsheet, sheet 'data') for each of the three priors 'global', 'equal' and 'equal-M'.

Table 7. Percentage of garnets assigned to the respective host rock/facies groups, i.e. highest probability for group A (eclogite), B (amphibolite), C (granulite), D (ultramafic) or E (plutonic), calculated separately for each of the three suggested priors ('global', 'equal' and 'equal-M', as introduced in Section 5.2). All examples are from crystalline rocks taken from the literature. None of the samples is part of the database used for the discrimination scheme. Bold numbers indicate overall correct classification, i.e., highest percentage obtained for the correct host rock/facies group. 
Table 8. Results of garnet classification for examples from sediments and sedimentary rocks, taken from the literature. All calculations are done with prior 'equal-M'. Left columns shows the percentage of garnets assigned with highest probability to one of the host rock groups $A$ (eclogite), B (amphibolite), $C$ (granulite), D (ultramafic) or $E$ (plutonic). The right column shows the averaged probabilities (closed geometric mean) for each of the groups. Highest percentages are marked bold. 

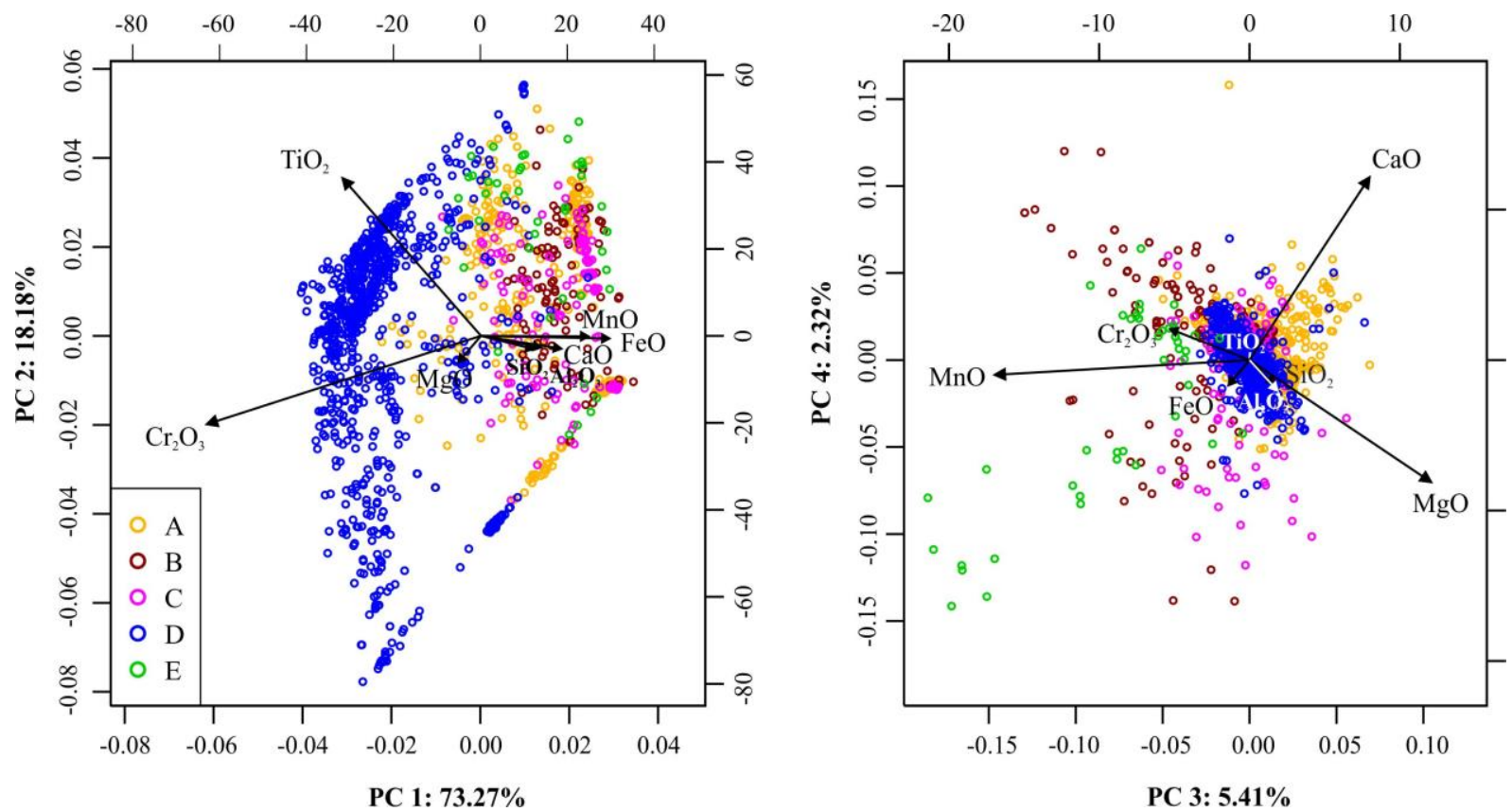

Figure 1 


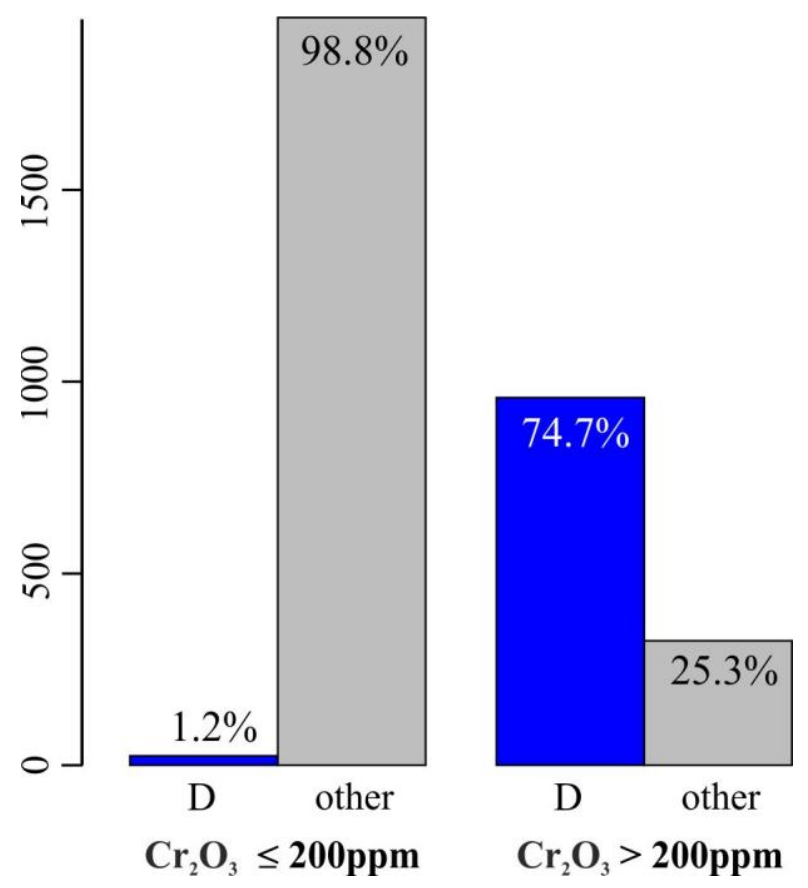

Figure 2 

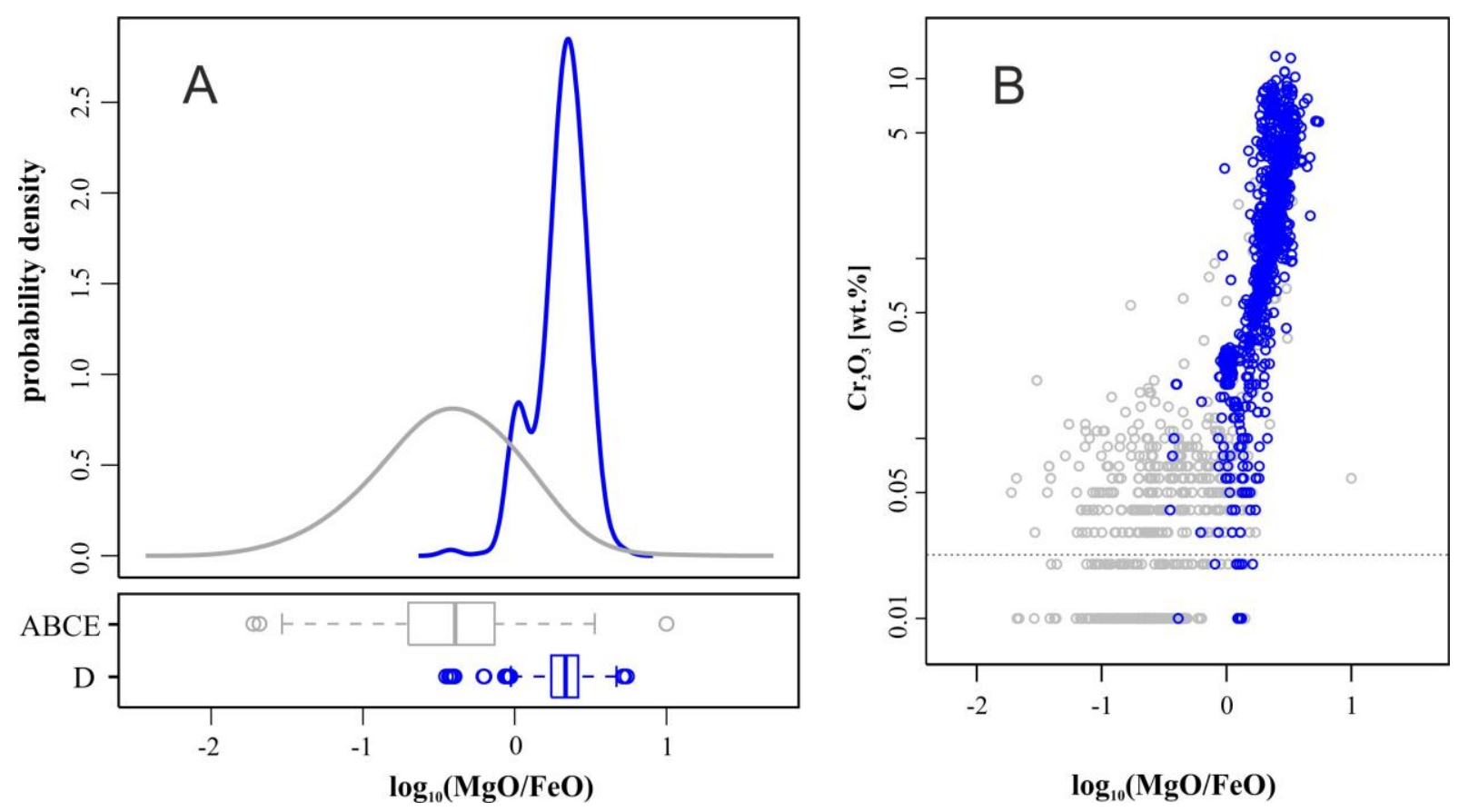

Figure 3 


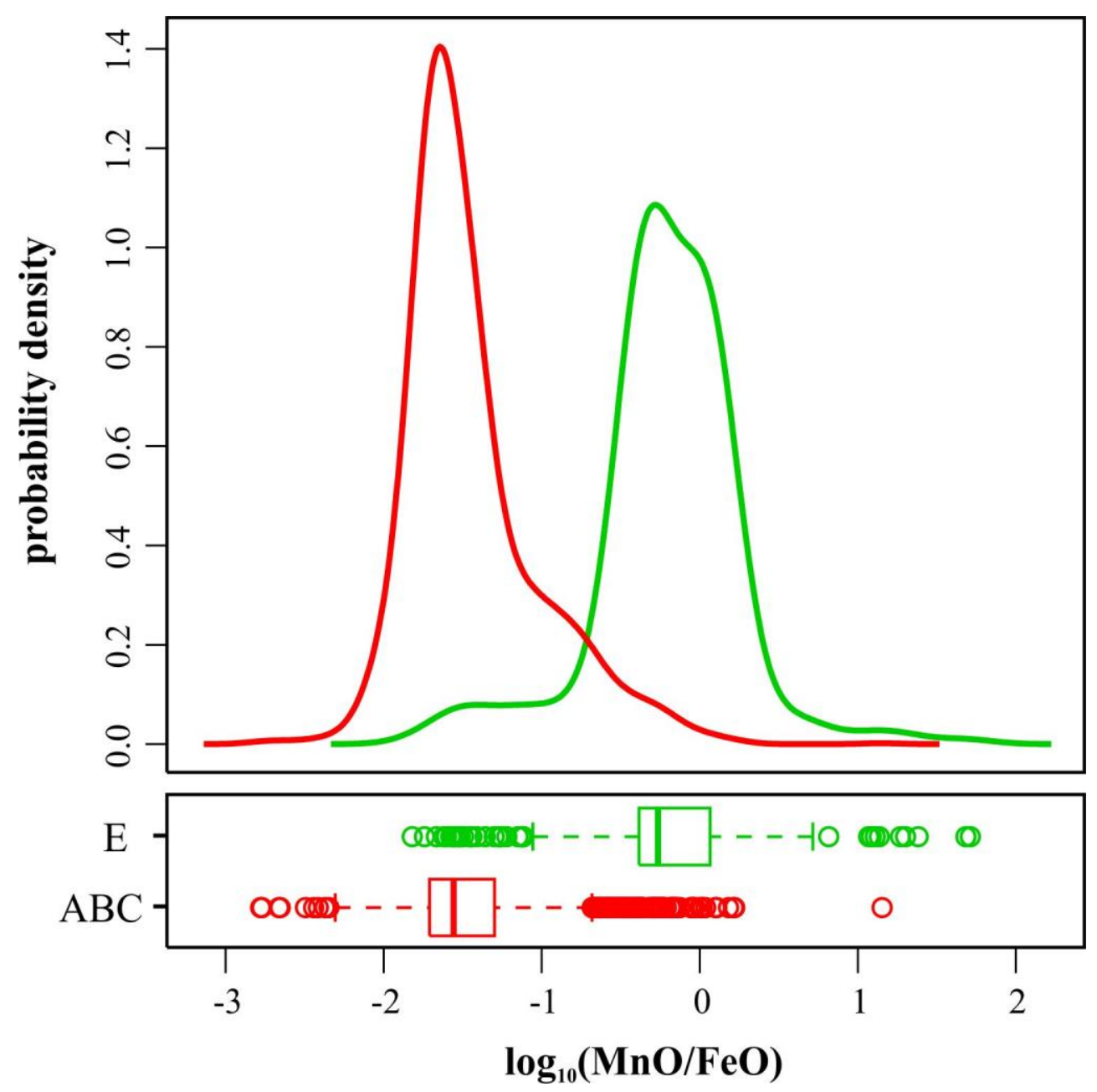

Figure 4 


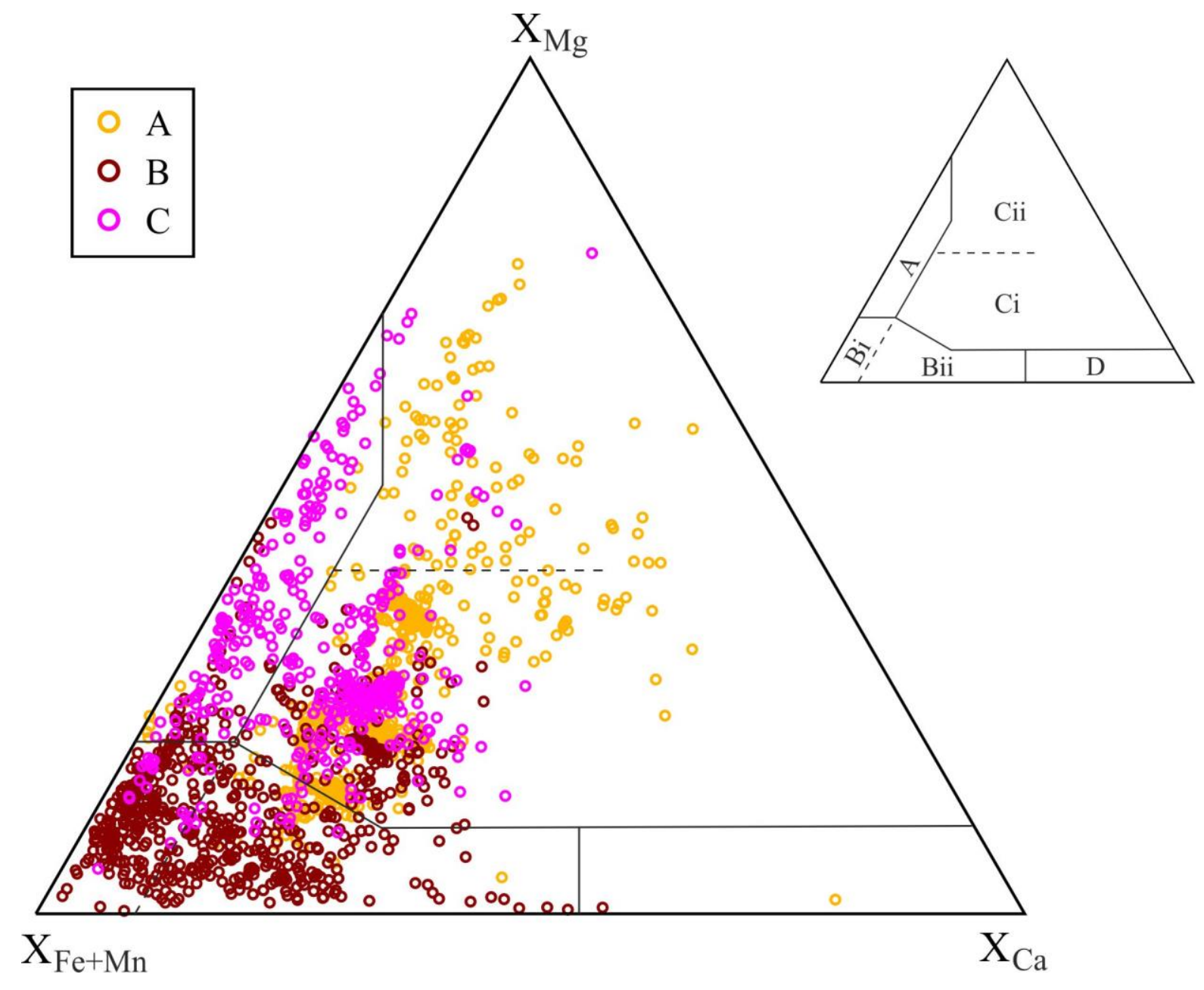

Figure 5 


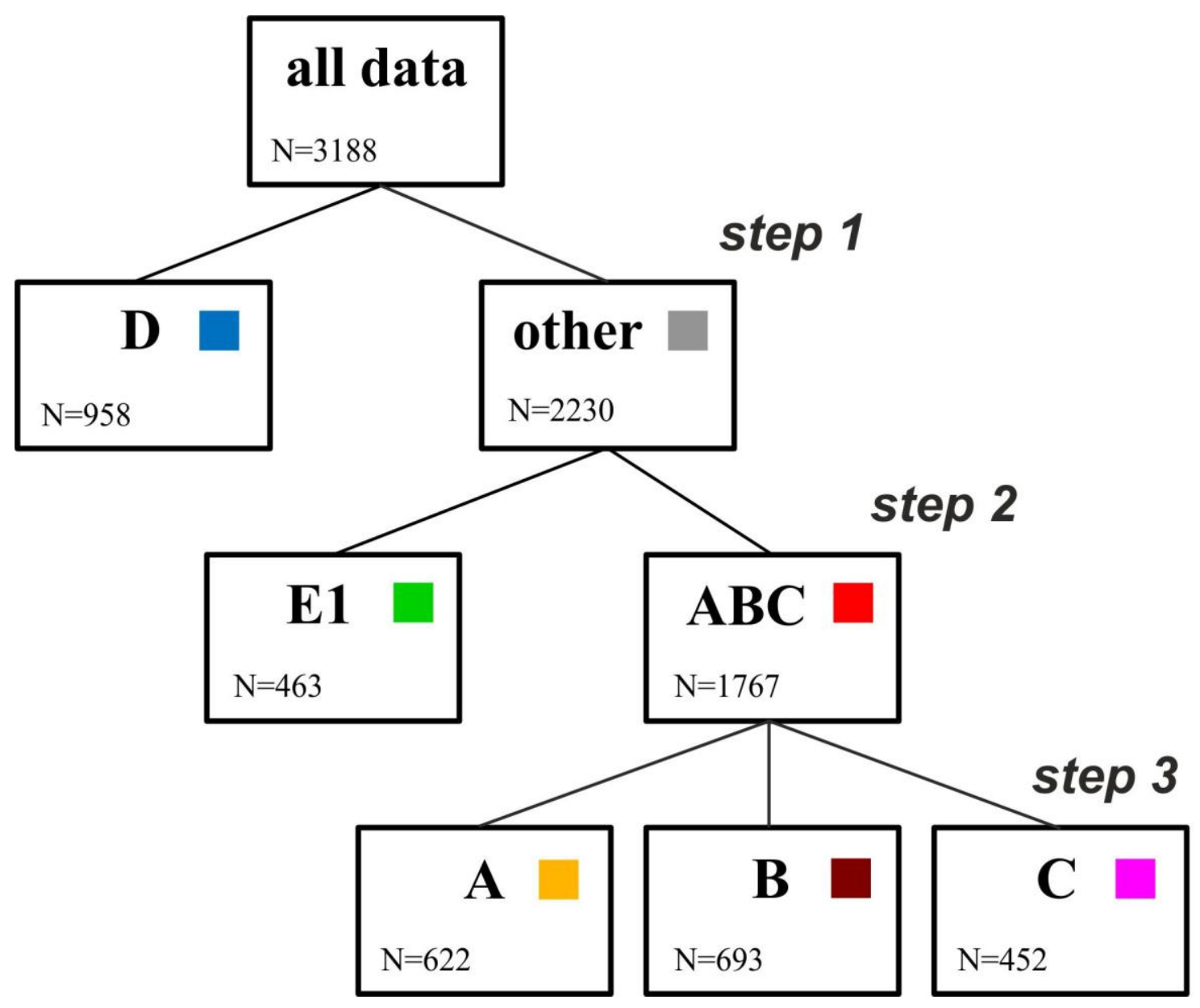

Figure 6 


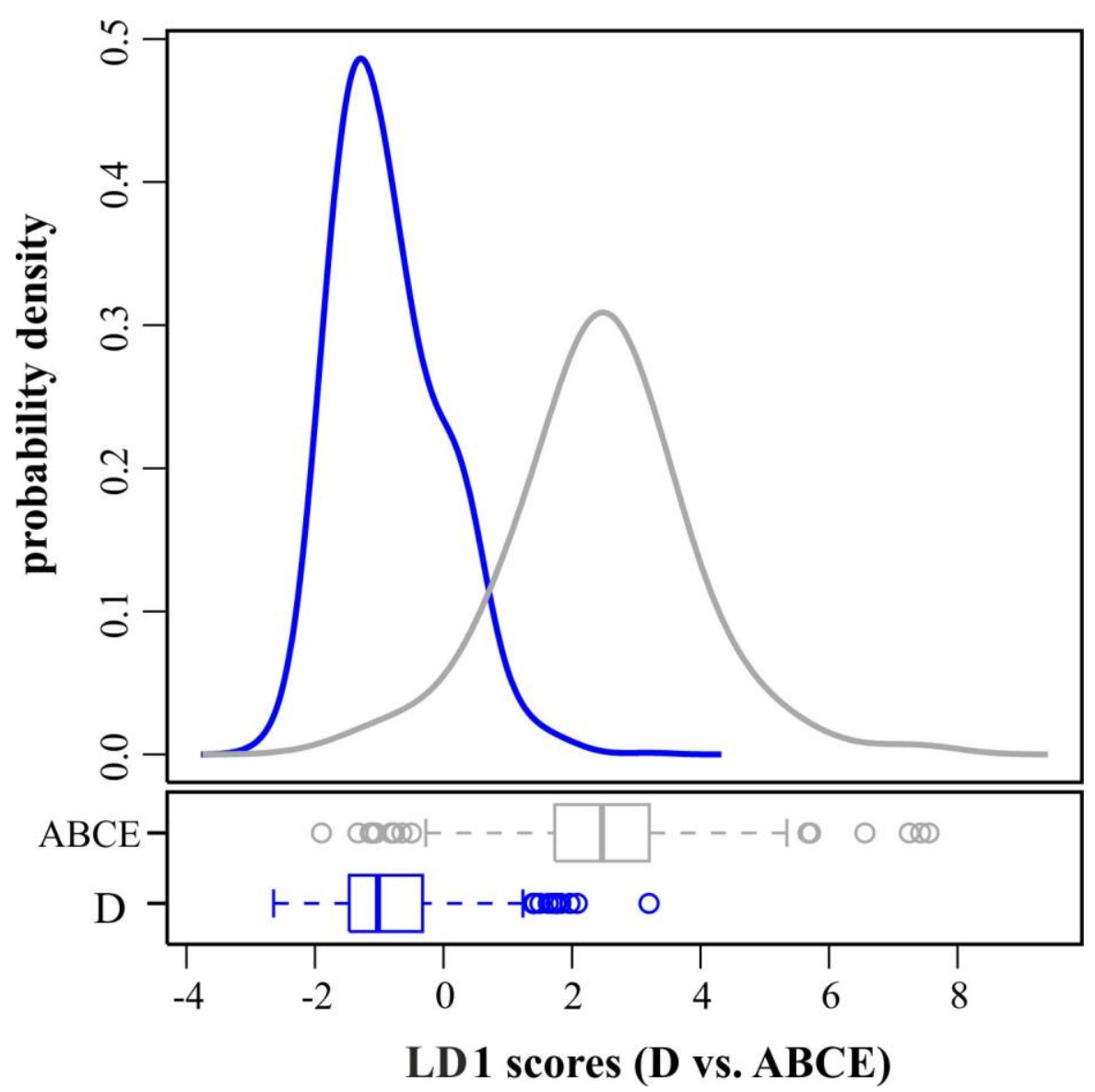

Figure 7 


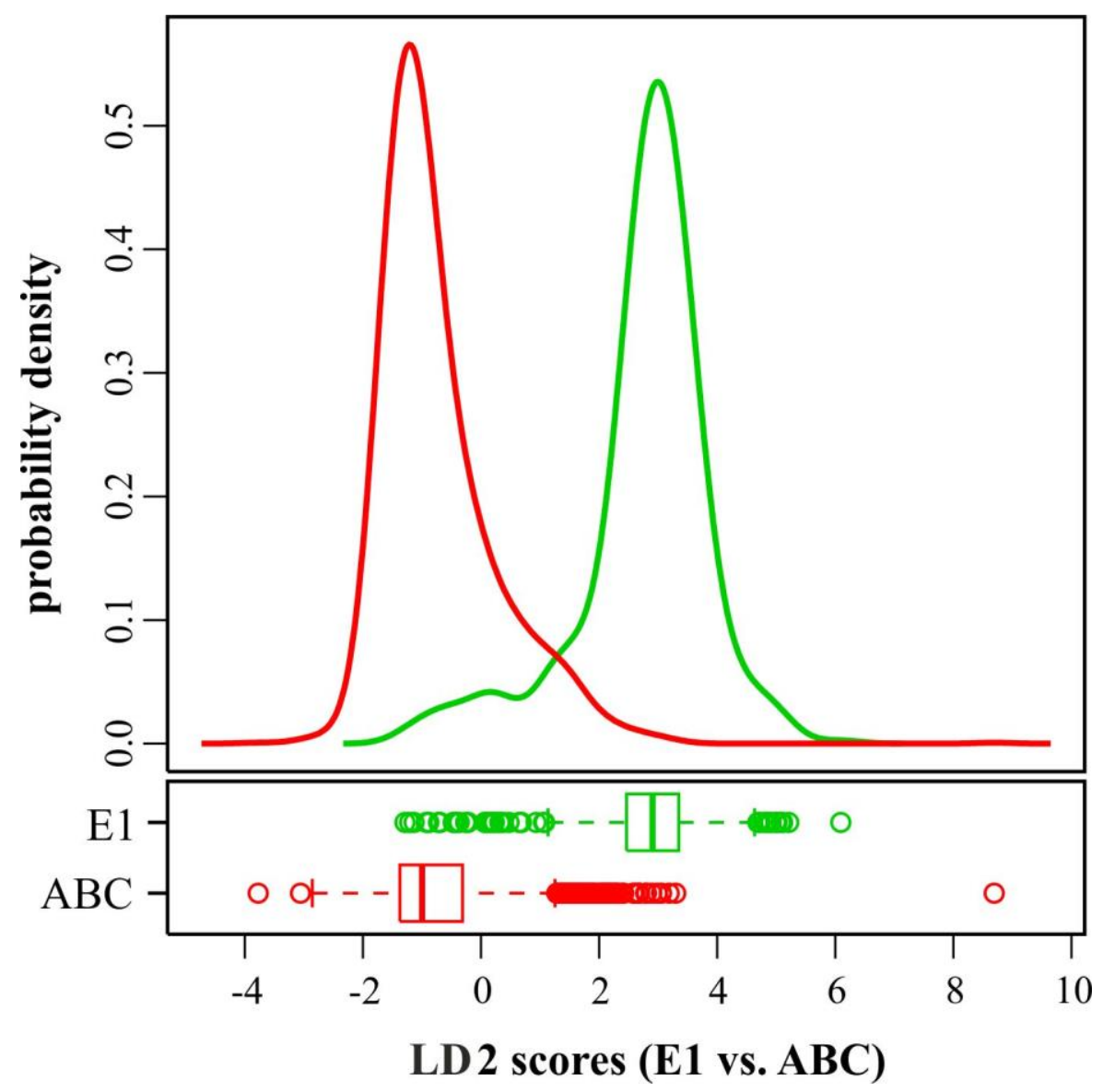

Figure 8 

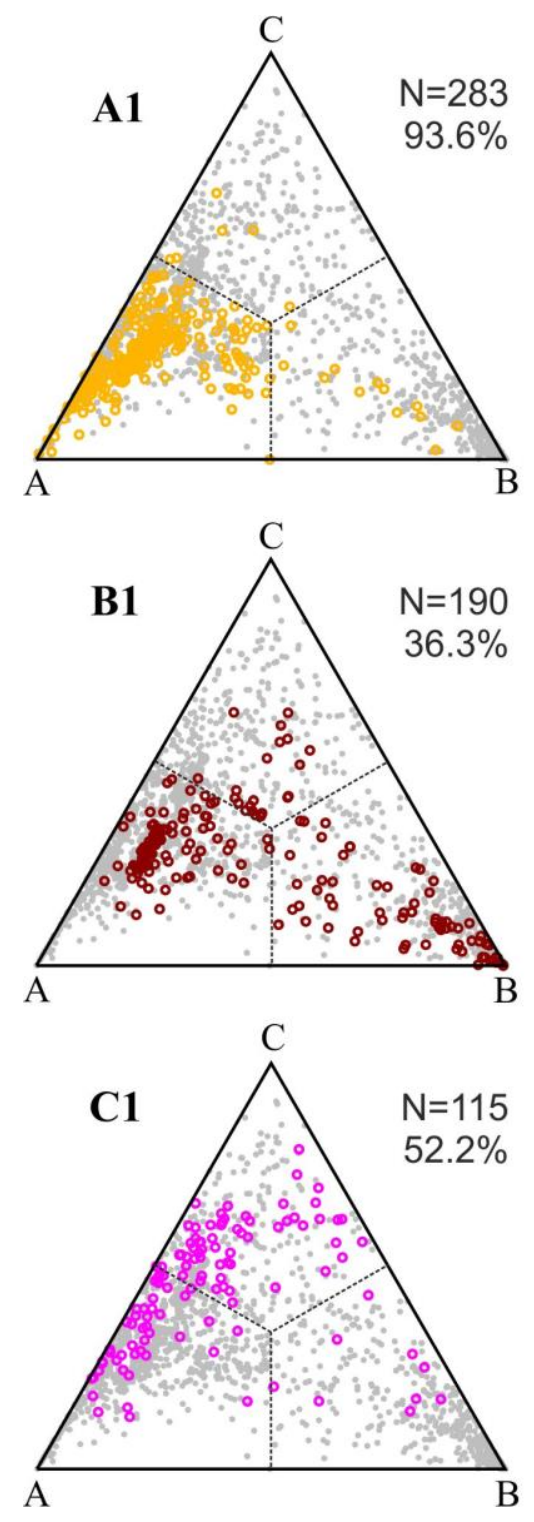
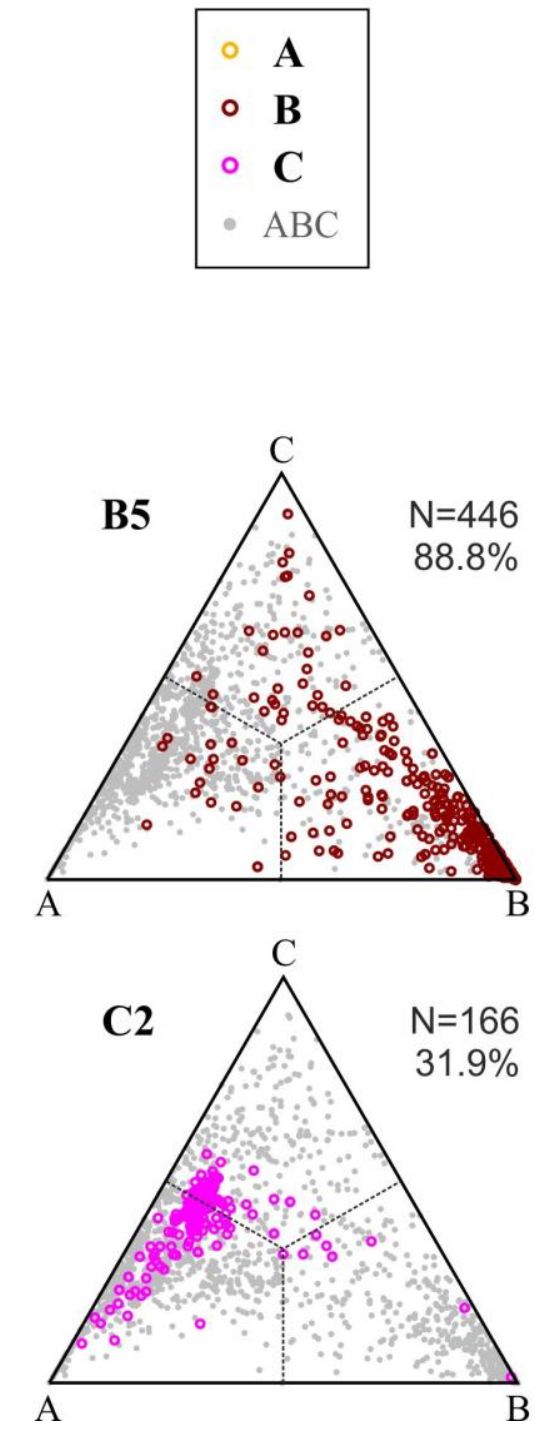
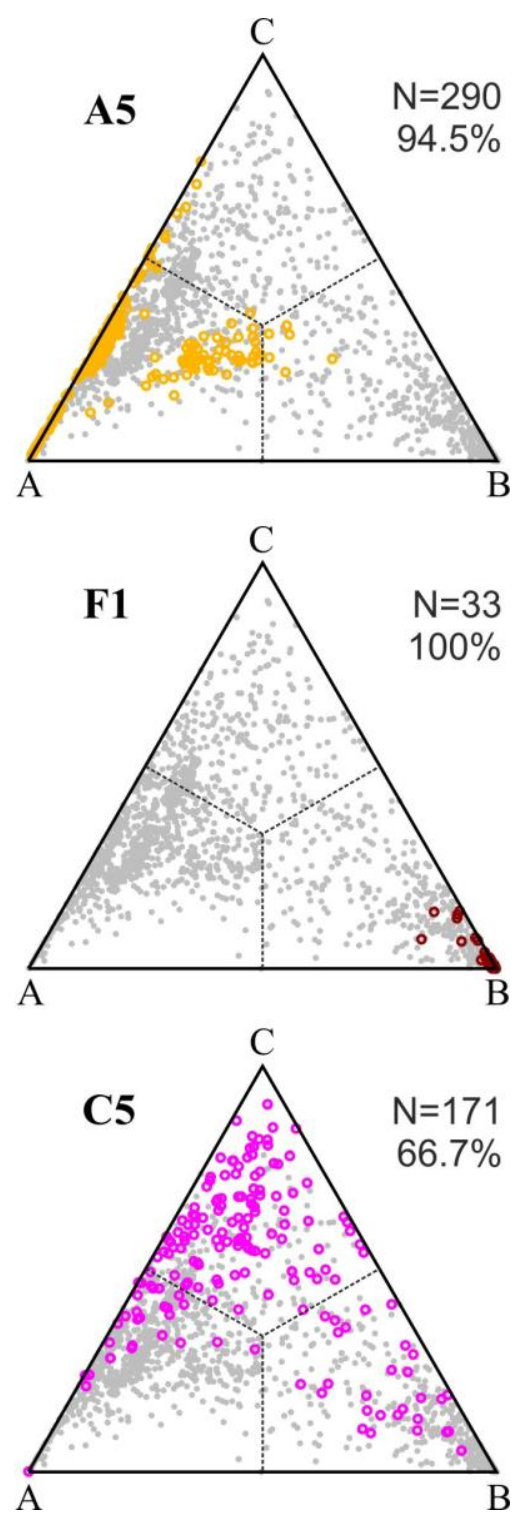

Figure 9 


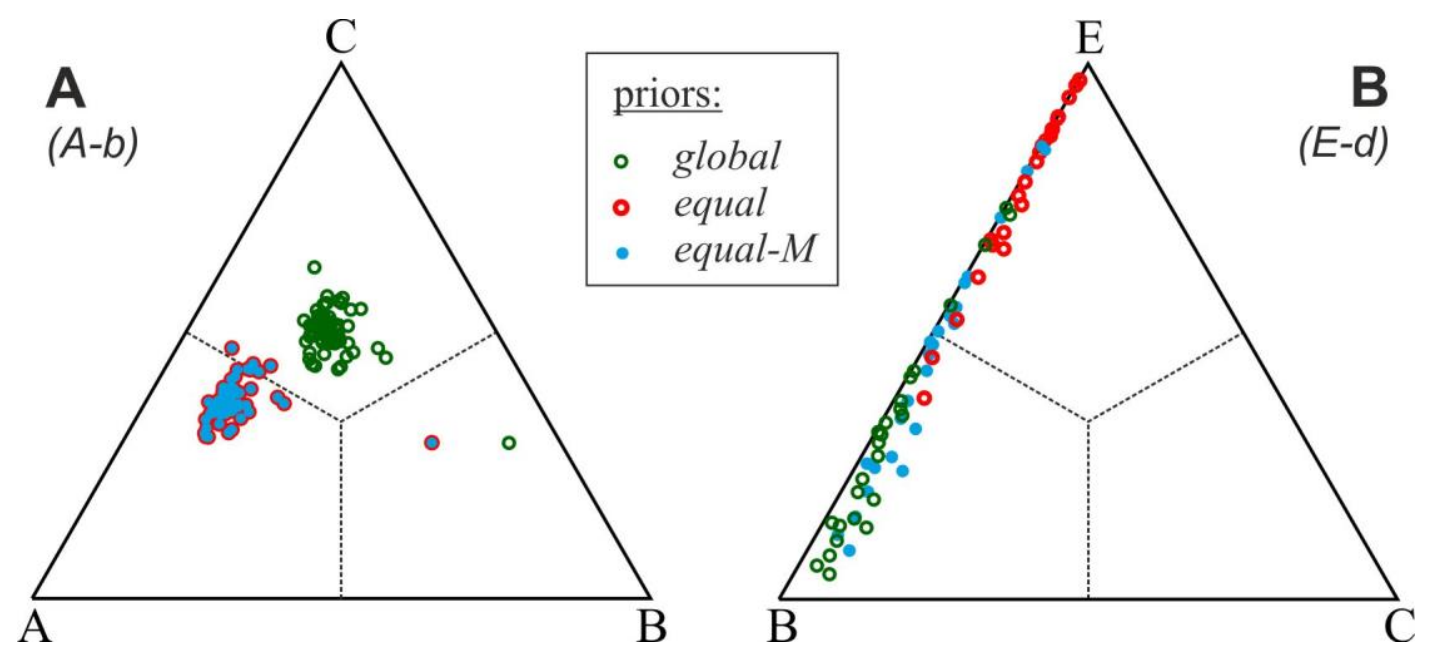

Figure 10 


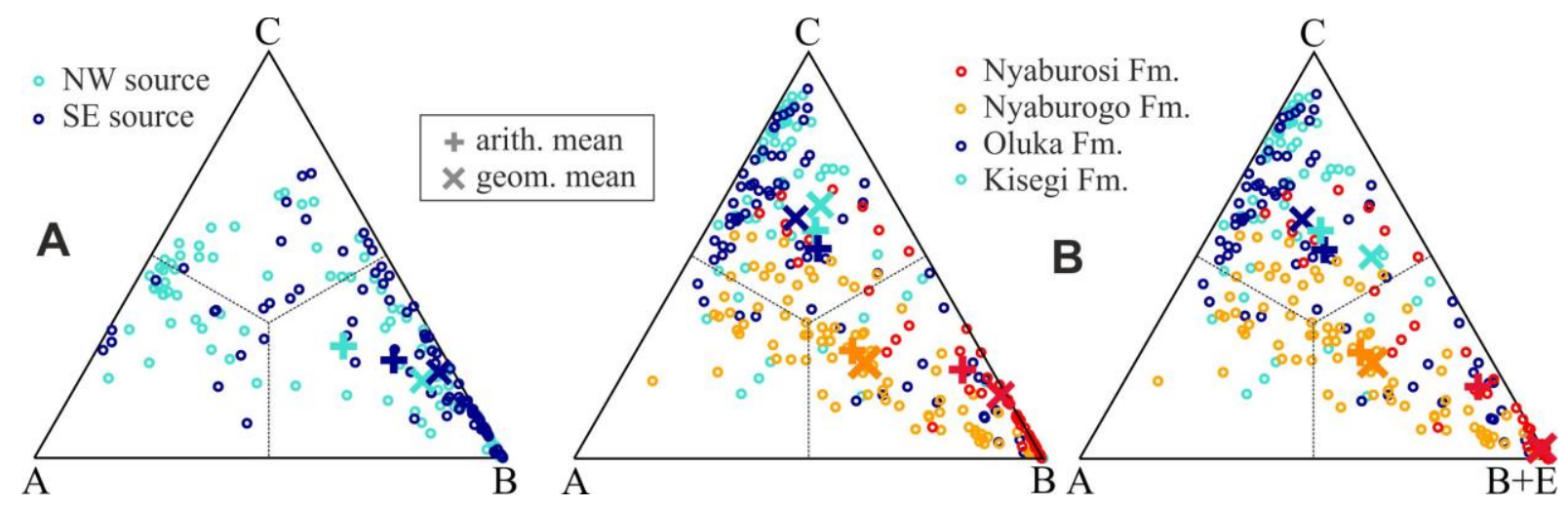

Figure 11 
Table 1

Groups / Subgroups

Number

A eclogite-facies

622

A1 mafic metaigneous 283

A2 felsic metaigneous $\quad 12$

A3 mafic metaigneous low-T 13

A5 metaigneous UHP 290

A6 metasedimentary 24

\begin{tabular}{|c|c|c|c|}
\hline B & amphibolite-facies & & 693 \\
\hline B1 & mafic metaigneous & 190 & \\
\hline B2 & felsic metaigneous & 3 & \\
\hline B5 & metasedimentary & 446 & \\
\hline B6 & metasedimentary low-T & 21 & \\
\hline $\mathrm{F} 1$ & greenschist metasedimentary & 33 & \\
\hline C & granulite-facies & & 452 \\
\hline $\mathrm{C} 1$ & mafic metaigneous & 115 & \\
\hline $\mathrm{C} 2$ & felsic metaigneous & 166 & \\
\hline $\mathrm{C} 5$ & metasedimentary & 171 & \\
\hline D & ultramafic rocks & & 958 \\
\hline $\mathrm{D}$ & ultramafic rocks & 958 & \\
\hline $\mathbf{E}$ & igneous rocks & & 463 \\
\hline E1 & felsic plutonic & 463 & \\
\hline E2 & mafic plutonic & 75 & \\
\hline E3 & felsic volcanic & 70 & \\
\hline E4 & mafic volcanic & 131 & \\
\hline
\end{tabular}


Table 2

\begin{tabular}{|l|r|r|r|}
\hline \multicolumn{2}{|l|}{$\begin{array}{l}\text { Misclassification: } \\
2.92 \%\end{array}$} & \multicolumn{2}{|c|}{ True type } \\
\cline { 3 - 4 } & \multicolumn{1}{|c|}{$\mathrm{D}$} & \multicolumn{1}{c|}{ ABCE } \\
\hline Predicted type & $\mathrm{D}$ & 916 & 51 \\
\cline { 2 - 4 } & ABCE & 42 & 2179 \\
\hline \multicolumn{2}{|c|}{ Correct classification } & $95.62 \%$ & $97.71 \%$ \\
\hline
\end{tabular}


Table 3

\begin{tabular}{|l|r|r|r|}
\hline \multicolumn{2}{|l|}{$\begin{array}{l}\text { Misclassification: } \\
6.05 \%\end{array}$} & \multicolumn{2}{c|}{ True type } \\
\cline { 3 - 4 } & ABC & \multicolumn{1}{c|}{ E1 } \\
\hline Predicted type & ABC & 1682 & 50 \\
\cline { 2 - 4 } & E1 & 85 & 413 \\
\hline \multicolumn{2}{|c|}{ Correct classification } & $95.18 \%$ & $89.20 \%$ \\
\hline
\end{tabular}


Table 4

\begin{tabular}{|r|r|r|r|r|}
\hline \multicolumn{2}{|c|}{ Misclassification: $25.86 \%$} & \multicolumn{3}{|c|}{ True type } \\
\cline { 3 - 5 } \multicolumn{2}{|c|}{} & \multicolumn{1}{|c|}{ A } & B & \multicolumn{1}{c|}{ C } \\
\hline Predicted type & A & 567 & 123 & 183 \\
\cline { 2 - 5 } & B & 31 & 518 & 44 \\
\cline { 2 - 5 } & C & 24 & 52 & 225 \\
\hline \multicolumn{2}{|c|}{ Correct classification } & $91.16 \%$ & $74.75 \%$ & $49.78 \%$ \\
\hline
\end{tabular}


Table 5

\begin{tabular}{|l|c|c|c|c|c|}
\cline { 2 - 6 } \multicolumn{1}{c|}{} & D & E1 & A & B & C \\
\hline Step 1 & $\mathrm{p}_{1}$ & \multicolumn{5}{|c|}{$1-\mathrm{p}_{1}$} \\
\hline Step 2 & $\mathrm{p}_{2}$ & & $1-\mathrm{p}_{2}$ \\
\hline Step 3 & & $\mathrm{p}_{\mathrm{A}}$ & $\mathrm{p}_{\mathrm{B}}$ & $\mathrm{p}_{\mathrm{C}}$ \\
\hline Integration & $\mathrm{p}_{1}$ & $\left(1-\mathrm{p}_{1}\right) \mathrm{p}_{2}$ & $\left(1-\mathrm{p}_{1}\right)\left(1-\mathrm{p}_{2}\right) \mathrm{p}_{\mathrm{A}}$ & $\left(1-\mathrm{p}_{1}\right)\left(1-\mathrm{p}_{2}\right) \mathrm{p}_{\mathrm{B}}$ & $\left(1-\mathrm{p}_{1}\right)\left(1-\mathrm{p}_{2}\right) \mathrm{p}_{\mathrm{C}}$ \\
\hline
\end{tabular}


Table 6

\begin{tabular}{|l|c|c|c|}
\hline group “averages” & $\begin{array}{c}\text { prior 'global' } \\
\text { [\%group] }\end{array}$ & $\begin{array}{c}\text { prior 'equal' } \\
\text { [\%group] }\end{array}$ & $\begin{array}{c}\text { prior 'equal-M' } \\
\text { [\%group] }\end{array}$ \\
\hline art1_D - (ultramafic) & $1.2 \% \mathrm{D}$ & $53.4 \% \mathrm{D}$ & $19.4 \% \mathrm{D}$ \\
\hline art2_E - (plutonic) & $94.7 \% \mathrm{E}$ & $99.3 \% \mathrm{E}$ & $97.3 \% \mathrm{E}$ \\
\hline art-3_A - (eclogite) & $39.5 \% \mathrm{~A}$ & $62.5 \% \mathrm{~A}$ & $62.6 \% \mathrm{~A}$ \\
\hline art-4_B - (amphibolite) & $82.2 \% \mathrm{~B}$ & $74.4 \% \mathrm{~B}$ & $74.7 \% \mathrm{~B}$ \\
\hline art-5_C - (granulite) & $66.5 \% \mathrm{C}$ & $52.0 \% \mathrm{C}$ & $52.1 \% \mathrm{C}$ \\
\hline
\end{tabular}


Table 7

\begin{tabular}{|c|c|c|c|c|c|}
\hline no. & $\begin{array}{l}\text { rock or facies / sample } \\
\text { (reference) }\end{array}$ & $N$ & $\begin{array}{c}\text { prior 'global' } \\
\text { [\%group] }\end{array}$ & $\begin{array}{l}\text { prior 'equal' } \\
\text { [\%group] }\end{array}$ & $\begin{array}{c}\text { prior 'equal }-M \text { ' } \\
\text { [\%group] }\end{array}$ \\
\hline A-a & $\begin{array}{l}\text { eclogite xenolithes / } \\
\text { numerous samples } \\
\text { (Kopylova et al., 2016) }\end{array}$ & 267 & $\mathbf{7 0 A}, 2 \mathrm{~B}, 28 \mathrm{C}$ & $\mathbf{9 3 A}, 2 \mathrm{C}, 5 \mathrm{D}$ & 96A, 4C \\
\hline A-b & $\begin{array}{l}\text { UHP eclogite / AK-N12 } \\
\text { (Krippner et al., 2016) }\end{array}$ & 59 & $2 \mathrm{~B}, 98 \mathrm{C}$ & $\mathbf{9 1 A}, 2 \mathrm{~B}, 7 \mathrm{C}$ & $\mathbf{9 1 A}, 2 \mathrm{~B}, 7 \mathrm{C}$ \\
\hline A-c & $\begin{array}{l}\text { mafic eclogite / AK-N38 } \\
\text { (Krippner et al., 2016) }\end{array}$ & 58 & $41 \mathrm{~A}, 7 \mathrm{~B}, 52 \mathrm{C}$ & 93A, 7B & 93A, 7B \\
\hline A-d & $\begin{array}{l}\text { mafic eclogite / A2-2a } \\
\text { (Krippner et al., 2015) }\end{array}$ & 38 & $11 \mathrm{~A}, 16 \mathrm{~B}, 73 \mathrm{C}$ & $\mathbf{7 1 A}, 3 \mathrm{~B}, 26 \mathrm{C}$ & $\mathbf{7 1 A}, 3 \mathrm{~B}, 26 \mathrm{C}$ \\
\hline B-a & $\begin{array}{l}\text { garnet mica schist } \\
\text { (Ren et al., 2015) }\end{array}$ & 23 & 100B & $100 B$ & 100B \\
\hline B-b & $\begin{array}{l}\text { mica schist / A2-2e } \\
\text { (Krippner et al., 2015) }\end{array}$ & 62 & $100 B$ & $100 B$ & 100B \\
\hline B-c & $\begin{array}{l}\text { mica schist } \\
\text { (Samadi et al., 2014) }\end{array}$ & 22 & 95B, 5E & 64B, $36 \mathrm{E}$ & 95B, 5E \\
\hline B-d & $\begin{array}{l}\text { amphibolite } \\
\text { (Bhowmik and Ao, 2016) }\end{array}$ & 13 & 62B, $38 \mathrm{E}$ & 62B, $38 \mathrm{E}$ & 62B, 38E \\
\hline $\mathrm{C}-\mathrm{a}$ & $\begin{array}{l}\text { var. granulites (see text) } \\
\text { (El-Shazly et al., 2011) }\end{array}$ & 28 & $71 B, 29 \mathrm{C}$ & $71 B, 29 \mathrm{C}$ & $71 B, 29 \mathrm{C}$ \\
\hline C-b & $\begin{array}{l}\text { metasediment. granulite } \\
\text { (Tong et al., 2014) }\end{array}$ & 4 & $50 \mathrm{~B}, \mathbf{5 0 C}$ & $25 \mathrm{~B}, 75 \mathrm{C}$ & $25 \mathrm{~B}, 75 \mathrm{C}$ \\
\hline $\mathrm{C}-\mathrm{c}$ & $\begin{array}{l}\text { metasediment. granulite } \\
\text { (Buchwaldt et al., 2003) }\end{array}$ & 11 & $55 \mathrm{~B}, 45 \mathrm{C}$ & $45 \mathrm{~B}, \mathbf{5 5 C}$ & $45 \mathrm{~B}, \mathbf{5 5 C}$ \\
\hline C-d & $\begin{array}{l}\text { UHT granulite } \\
\text { (Zhang et al., 2012a) }\end{array}$ & 4 & $100 \mathrm{C}$ & $100 \mathrm{C}$ & $100 \mathrm{C}$ \\
\hline C-e & $\begin{array}{l}\text { felsic granulite/ AK-N11 } \\
\text { (Krippner et al., 2016) }\end{array}$ & 59 & $73 \mathrm{~A}, 7 \mathrm{~B}, 20 \mathrm{C}$ & $100 \mathrm{~A}$ & $100 \mathrm{~A}$ \\
\hline D-a & $\begin{array}{l}\text { dunite } \\
\text { (Chen et al., 2017) }\end{array}$ & 4 & $50 \mathrm{C}, 50 \mathrm{E}$ & 100D & 100D \\
\hline D-b & $\begin{array}{l}\text { orthopyroxenite } \\
\text { (Chen et al., 2017) }\end{array}$ & 6 & $100 \mathrm{C}$ & $33 \mathrm{C}$, 67D & $100 \mathrm{C}$ \\
\hline D-c & $\begin{array}{l}\text { peridotite xenolith in } \\
\text { kimberlite } \\
\text { (Lock and Dawson, 1980) }\end{array}$ & 3 & $33 \mathrm{C}, 67 \mathrm{E}$ & 100D & 100D \\
\hline D-d & $\begin{array}{l}\text { peridotite xenolith in } \\
\text { kimberlite (Skinner, 1989) }\end{array}$ & 9 & $56 \mathrm{C}, 44 \mathrm{E}$ & 100D & 78D, 22E \\
\hline E-a & $\begin{array}{l}\text { A-type granite } \\
\text { (Zhang et al., 2012b) }\end{array}$ & 18 & $100 \mathrm{E}$ & $100 E$ & $100 \mathrm{E}$ \\
\hline E-b & $\begin{array}{l}\text { monzogranite, Af-granite } \\
(\mathrm{Wu} \text { et al., 2004) }\end{array}$ & 11 & $27 \mathrm{~B}, 73 \mathrm{E}$ & $27 \mathrm{~B}, 73 \mathrm{E}$ & 27B, $73 E$ \\
\hline E-c & REE-rich biotite granite & 12 & $100 \mathrm{E}$ & $100 \mathrm{E}$ & $100 \mathrm{E}$ \\
\hline
\end{tabular}




\begin{tabular}{|c|l|c|c|c|c|}
\hline & (Wang et al., 2003) & & & & \\
\hline E-d & $\begin{array}{l}\text { S-type granite } \\
\text { (Dahlquist et al., 2007) }\end{array}$ & 25 & $84 \mathrm{~B}, 16 \mathrm{E}$ & $8 \mathrm{~B}, \mathbf{9 2 E}$ & $60 \mathrm{~B}, 40 \mathrm{E}$ \\
\hline E-e & $\begin{array}{l}\text { S-type granite, rest. garnet } \\
\text { (Jung et al., 2001) }\end{array}$ & 17 & $\mathbf{8 8 B}^{*}, 12 \mathrm{E}$ & $\mathbf{7 6 B}^{*}, 24 \mathrm{E}$ & $\mathbf{8 8 B}, 12 \mathrm{E}$ \\
\hline
\end{tabular}

$N$ - number of garnet analyses

* - correctly classified because these garnets are refractory residues from partial melting (see text) 
Table 8

\begin{tabular}{|c|l|c|c|c|}
\hline no. & $\begin{array}{l}\text { rock or facies / sample } \\
\text { (reference) }\end{array}$ & $N$ & $\begin{array}{c}\text { percentage of garnets } \\
\text { assigned to each group }\end{array}$ & $\begin{array}{c}\text { averaged probabilities } \\
\text { for each group }\end{array}$ \\
\hline S-a & $\begin{array}{l}\text { gneiss pebble / AK-N13- } \\
\text { 2d (Krippner et al., 2016) }\end{array}$ & 42 & $\mathbf{1 0 0 B}$ & A9, B88, C3 \\
\hline S-b & $\begin{array}{l}\text { gneiss pebble / AK-N13- } \\
\text { 2c (Krippner et al., 2016) }\end{array}$ & 60 & 5A, 95C & A28, B18, C54 \\
\hline S-c & $\begin{array}{l}\text { Ulvesund / AK-N8-1 } \\
\text { (Krippner et al., 2016) }\end{array}$ & 99 & 38A, 4B, 58C & A23, B20, C57 \\
\hline S-d & $\begin{array}{l}\text { NW source (von Eynatten } \\
\text { and Gaupp, 1999) }\end{array}$ & 94 & 24A, 47B, 20C, 9E & 10A, 66B, 24C \\
\hline & $\begin{array}{l}\text { SE source (von Eynatten } \\
\text { and Gaupp, 1999) }\end{array}$ & 84 & 12A, 60B, 17C, 12E & 4A, 75B, 21C, 1E \\
\hline S-e & $\begin{array}{l}\text { Kisegi Fm., M. Miocene } \\
\text { (Schneider et al., 2016) }\end{array}$ & 53 & 9A, 9B, 70C, 11E & 16A, 21B, 62C \\
\hline & $\begin{array}{l}\text { Oluka Fm., U. Miocene } \\
\text { (Schneider et al., 2016) }\end{array}$ & 69 & 6A, 25B, 70C & 23A, 18B, 59C \\
\hline & $\begin{array}{l}\text { Nyaburogo Fm., L. Plioc. } \\
\text { (Schneider et al., 2016) }\end{array}$ & 81 & 22A, 58B, 20C & 26A, 50B, 24C \\
\hline & $\begin{array}{l}\text { Nyaburosi Fm., L. Pleist. } \\
\text { (Schneider et al., 2016) }\end{array}$ & 48 & 33B, 21C, 46E & 1A, 64B, 12C, 24E \\
\hline
\end{tabular}

$N$ - number of garnet analyses 